\title{
Subtribos Eugeniinae O. Berg e Myrtinae O. Berg (Myrtaceae) na Restinga da Marambaia, RJ, Brasil ${ }^{1}$
}

\author{
Marcelo da Costa Souza ${ }^{2,3}$ e Marli Pires Morim²
}

Recebido em 17/01/2007. Aceito em 24/09/2007

\begin{abstract}
RESUMO - (Subtribos Eugeniinae O. Berg e Myrtinae O. Berg (Myrtaceae) na Restinga da Marambaia, RJ, Brasil). Myrtaceae é uma das famílias com maior riqueza de espécies nas Restingas. O objetivo deste trabalho foi o levantamento das subtribos Eugeniinae e

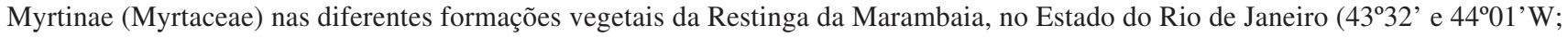
$23^{\circ} 01^{\prime}$ e $\left.23^{\circ} 06^{\prime} S\right)$. Foram registrados 17 táxons para Eugeniinae e quatro para Myrtinae, sendo a subtribo com maior número de espécies Eugeniinae. Apresenta-se uma chave de identificação para as espécies, bem como descrições, ilustrações, dados relativos às épocas de floração e de frutificação e distribuição geográfica.
\end{abstract}

Palavras-chave: Eugeniinae, Myrtinae, Myrtaceae, florística, taxonomia, Restinga da Marambaia

ABSTRACT - (Subtribes Eugeniinae O. Berg and Myrtinae O. Berg (Myrtaceae) at Marambaia Restinga, Rio de Janeiro State, Brazil). The Myrtaceae is one of the most species-rich families in "restinga" vegetation. This study aimed to survey the subtribes Eugeniinae and

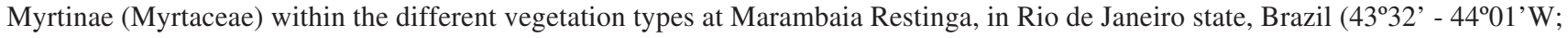
$23^{\circ} 01^{\prime}-23^{\circ} 06$ 'S). Seventeen taxa of Eugeniinae and four of Myrtinae were found, the subtribe with greatest number of species being the Eugeniinae. A species key is presented, as well as descriptions, illustrations, data on flowering and fruiting periods, and the geographic distribution of these species.

Key words: Eugeniinae, Myrtinae, Myrtaceae, floristics, taxonomy, Marambaia Restinga

\section{Introdução}

As Myrtaceae brasileiras pertencem à tribo Myrteae, formando um grupo filogeneticamente coeso (Wilson et al. 2001). Candolle (1826), com base na estrutura dos embriões, dividiu a tribo Myrteae em três grupos. Berg (1855; 1856a; 1856b; 1857; 1858; 1859) considerou os três grupos de Candolle como subtribos: Myrciinae O. Berg, Myrtinae O. Berg e Eugeniinae O. Berg.

A base de informações para a família são os tradicionais trabalhos de Berg $(1857 ; 1858 ; 1859)$ e Kiaerskou (1893) com informações muito escassas que dificultam a identificação das espécies, seja pela ausência de chaves para identificação ou pela difícil interpretação das descrições. Nestes trabalhos foram catalogados 332 táxons para o Rio de Janeiro.
A família Myrtaceae tem uma grande representatividade na flora do Rio de Janeiro como comprovado nos levantamentos florísticos e fitossociológicos realizados nas diferentes regiões do Estado. As coleções de herbários são numerosas, embora ainda haja um grande número de espécimes indeterminados. Os levantamentos florísticos, associados a tratamentos taxonômicos da família no Estado, restringem-se a áreas de Floresta Pluvial Atlântica (Barroso \& Perón 1994; Barroso \& Marques 1997). Estudos em ambientes de Restinga são inexistentes, embora o grupo esteja entre as três primeiras famílias com maior riqueza de espécies (Araujo 2000).

O presente trabalho tem como objetivo apresentar os resultados sobre a diversidade da família nas diferentes formações vegetais da Restinga da

\footnotetext{
1 Parte da Dissertação de Mestrado do primeiro Autor, Programa de Pós-Graduação em Botânica da Escola Nacional de Botânica Tropical, Instituto de Pesquisas Jardim Botânico do Rio de Janeiro

2 Instituto de Pesquisas Jardim Botânico do Rio de Janeiro, Diretoria de Pesquisa Científica, Rua Pacheco Leão 915, Jardim Botânico, 22460-030 Rio de Janeiro, RJ, Brasil

3 Autor para correspondência: msouza@jbrj.gov.br
} 
Marambaia, bem como o tratamento taxonômico para as subtribos Eugeniinae e Myrtinae, a exemplo do estudo realizado na subtribo Myrciinae (Souza et al. 2007).

\section{Material e métodos}

A Restinga da Marambaia localiza-se no Estado do Rio de Janeiro, compreendida pelos municípios do Rio de Janeiro, Itaguaí e Mangaratiba, entre os meridianos $43^{\circ} 32^{\prime}$ e $44^{\circ} 01^{\prime} \mathrm{W}$ e os paralelos $23^{\circ} 01^{\prime}$ e $23^{\circ} 06^{\prime}$ S. É formada por uma longa faixa de areia, que separa a Baía de Sepetiba do Oceano Atlântico, abrangendo uma área de aproximadamente 4.940 ha e uma extensão de cerca de $40 \mathrm{~km}$. Menezes \& Araujo (2005) reconhecem 11 formações vegetais na Restinga da Marambaia: quatro formações herbáceas (herbácea aberta de praia, herbácea fechada inundável, herbácea fechada inundada e herbácea fechada de cordão arenoso), quatro formações arbustivas (arbustiva aberta não inundável, arbustiva aberta inundável, arbustiva fechada de cordão arenoso e arbustiva fechada de pós-praia) e três formações florestais (floresta inundada, floresta inundável e floresta de cordão arenoso).

O trabalho de campo abrangeu o período de 2000 a 2004 e todos os procedimentos referentes à coleta de exemplares seguem Souza et al. (2007).

As coleções dos herbários RBR, RB, R, GUA, CVRD e CEPEC foram consultadas a fim de verificar a distribuição geográfica e épocas de floração e frutificação das espécies. As siglas dos herbários visitados estão de acordo com Holmgren et al. (1990).

A terminologia utilizada nas descrições taxonômicas seguiu: Ribeiro et al. (1999) e Marchiori (1995), dados dendrológicos; Harrington \& Durrel (1957), tipos de indumento; Hickey (1973), arquitetura foliar; Barroso et al. (1999), tipos de frutos e de embriões. As estruturas que integram a inflorescência seguiram a terminologia de Briggs \& Johnson (1979), assim como os tipos de inflorescências descritos como mônades e dicásios (Fig. 89, 93, 104). O tipo racemo "stenocalyx" (Fig. $1,19,25,27,47,53)$ seguiu o conceito de Barroso et al. (1984) e o tipo fascículo (Fig. 3, 8, 13, 32, 37, $42,58,63,68,73,78)$ foi adotado de Landrum \& Kawasaki (1997), embora modificado para incluir também as flores com antopódio muito curto. O

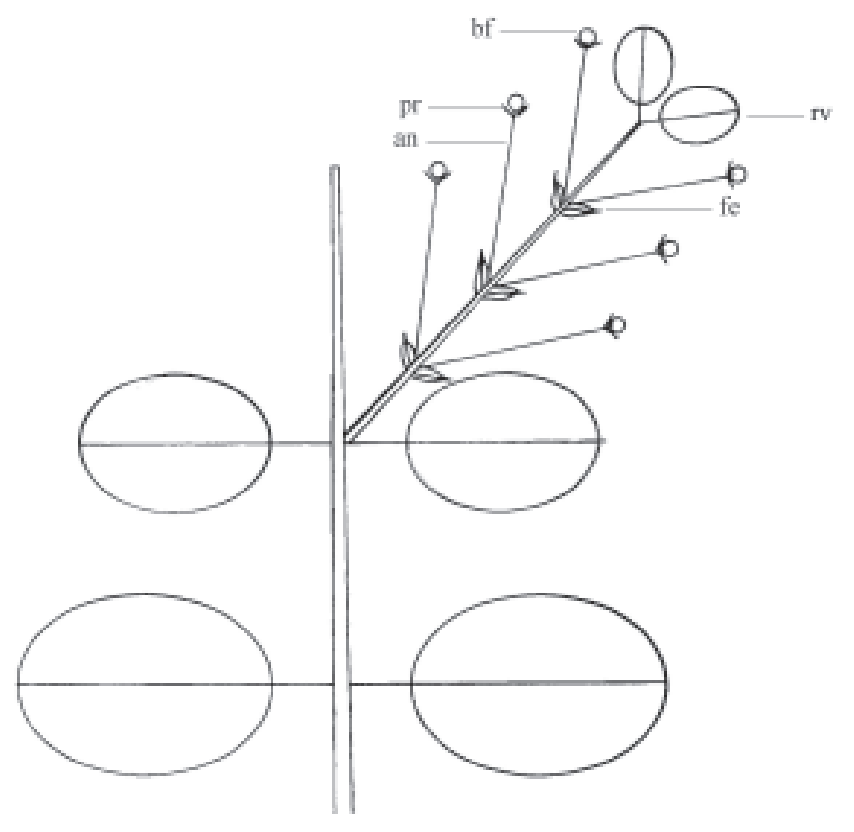

Figura 1. Esquema da inflorescência do tipo racemo "stenocalyx". an - antopódio, bf - botão floral, fe - ferofilo, pr - profilo, rv - ramo vegetativo.

material foi depositado no herbário do Departamento de Botânica da Universidade Federal Rural do Rio de Janeiro (RBR) com duplicatas no herbário do Instituto de Pesquisas Jardim Botânico do Rio de Janeiro (RB).

\section{Resultados e discussão}

A família Myrtaceae na Restinga da Marambaia abrange três subtribos, às quais estão subordinados 11 gêneros, perfazendo um total de 30 espécies. Os gêneros estão subordinados às subtribos Eugeniinae (4), Myrciinae (4) e Myrtinae (3). A subtribo com maior número de espécies é Eugeniinae (17), seguida de Myrciinae (9) e Myrtinae (4). O grande número de espécies observado em Eugeniinae pertence, principalmente, ao gênero Eugenia (13). As espécies da subtribo Myrciinae foram tratadas em Souza et al. (2007).

As espécies ocorrem em sete do total das onze formações vegetais definidas para a Restinga de Marambaia. A formação que apresenta a maior riqueza de espécies é a floresta de cordão arenoso (23), seguida pela formação arbustiva fechada de cordão arenoso (19) e formação arbustiva aberta não inundável (13). 
Chave de identificação para as espécies das subtribos

Eugeniinae e Myrtinae (Myrtaceae) da Restinga da Marambaia

1. Inflorescências em mônades ou dicásios (Subtribo Myrtinae)

2. Botão floral com cálice fechado ou aberto no ápice, lobos caliciniais indistintos; estigma globoso

3. Botão floral globoso-obovado; cálice aberto no ápice 7.1. Psidium catlleyanum

3. Botão floral em forma de "8", constricto logo acima do ovário; cálice totalmente fechado

2. Botão floral com cálice aberto, com 4 lobos caliciniais distintos; estigma punctiforme

4. Folhas com ápice acuminado e mucronado; flores com androceu com mais de 20 estames 5.1. Blepharocalyx salicifolius

4. Folhas com ápice obtuso ou arredondado; flores com androceu de 5-8 estames 6.1. Myrrhinium atropurpureum

1. Inflorescências em fascículos ou racemos "stenocalyx" (Subtribo Eugeniinae)

5. Botão floral com cálice fechado, lobos caliciniais indistintos

6. Cálice abrindo-se por uma caliptra

3.1. Neomitranthes obscura

6. Cálice abrindo-se em lobos irregulares 4.1. Plinia ilhensis

5. Botão floral com cálice aberto, com 4 lobos caliciniais distintos

7. Flores com hipanto prolongado acima do ovário, com os lobos decíduos logo após a floração

8. Folhas 25-60×10-30 mm; pecíolo com 5-8 mm compr.; ápice longo-acuminado

2.1. Myrciaria floribunda

8. Folhas 15-25×5-8 mm; pecíolo com até $1 \mathrm{~mm}$ compr.; ápice agudo 2.2. Myrciaria tenella

7. Flores sem hipanto prolongado, com lobos persistentes após a floração

9. Inflorescência do tipo racemo "stenocalyx"

10. Flores com hipanto e ovário 8-costados; fruto 8-costado

11. Profilos persistentes na antese e ocultando o ovário; lobos do cálice foliáceos ultrapassando o globo petalífero 1.5. Eugenia neonitida

11. Profilos decíduos; lobos do cálice não foliáceos e não ultrapassando o globo petalífero

12. Folhas elípticas ou oblongas, pontuações densas na face abaxial, visíveis a olho nu; nervuras secundárias pouco evidentes em ambas as faces; nervura marginal inconspícua; frutos maduros atropurpúreos, com lobos do cálice roxos 1.11. Eugenia sulcata

12. Folhas ovadas ou elípticas, pontuações não visíveis a olho nu em nenhuma das faces; nervuras secundárias visíveis e salientes na face abaxial; nervura marginal conspícua; frutos maduros vermelhos, com lobos do cálice verdes 1.12. Eugenia uniflora

10. Flores com hipanto e ovário não costados; frutos não costados

13. Plantas glabras; folhas obovadas ou oblongas com pecíolos 8-13 mm compr.; raquis $20-40 \mathrm{~mm}$ compr.; botões florais $8-10 \mathrm{~mm}$ compr. 1.2. Eugenia brasiliensis

13. Plantas com pecíolos, face abaxial das folhas e quando novas também a abaxial, antopódio, flores e ovário ferrugíneo-vilosos; folhas elípticas ou oval-oblongas com pecíolos 1-5 mm compr.; raquis 3-13 mm compr.; botões florais $4 \mathrm{~mm}$ compr.

1.6. Eugenia neosilvestris

9. Inflorescência em fascículo

14. Cálice ocultando o globo petalífero

15. Lobos do cálice de tamanhos iguais 1.4. Eugenia excelsa

15. Lobos do cálice de tamanhos desiguais

16. Profilos conados, ocultando o ovário 
17. Folhas com pontuações não visíveis a olho nu; nervuras secundárias 6-10 pares, pouco evidentes ou invisíveis em ambas as faces; fascículos com 4-6 flores 1.7. Eugenia oxyoentophylla

17. Folhas com pontuações translúcidas densas e evidentes a olho nu em ambas as faces; nervuras secundárias 8-10 pares visíveis em ambas as faces; fascículos com 2 flores 1.13. Eugenia sp.

16. Profilos não conados, não ocultando o ovário

18. Ramos e folhas novas, pecíolos, inflorescências, flores e frutos curtovelutinos; frutos, quando maduros, enegrecidos 1.1. Eugenia bahiensis

18. Ramos e folhas novas, inflorescências glabras ou esparso-pubérulas; frutos, quando maduros, vermelhos

1.8. Eugenia punicifolia

14. Cálice não ocultando o globo petalífero

19. Folhas com nervura principal saliente na face adaxial; bordo foliar com espessamento e pecíolo amarelados 1.3. Eugenia copacabanensis

19. Folhas com nervura principal plana ou sulcada na face adaxial; bordo revoluto e pecíolo não amarelados

20. Folhas com ápice longo-acuminado; nervuras secundárias tênues a imperceptíveis em ambas as faces 1.9. Eugenia rostrata

20. Folhas com ápice arredondado, obtuso ou curto obtuso-acuminado; nervuras secundárias visíveis em ambas as faces 1.10. Eugenia rotundifolia

Subtribo Eugeniinae

Inflorescências axilares terminais, em nós folhosos basais ou em nós afilos, em fascículo ou racemo "stenocalyx"; flores tetrâmeras, com cálice aberto ou fechado no botão floral, quando fechado abrindo-se pelo rasgamento do hipanto em 3-4 lobos irregulares ou por uma caliptra; pétalas presentes; androceu polistêmone; hipanto prolongado ou não acima do ápice do ovário; estigma punctiforme; ovário bilocular, 2 ou mais óvulos por lóculo. Fruto bacáceo ou bacídio, com 1-2 sementes; embrião eugenióide, com cotilédones unidos ou livres.

1. Eugenia L., Sp. pl. 1(1): 470. 1753.

Lectótipo: Eugenia uniflora L., designado por McVaugh (1956).

O gênero se distingue por apresentar flores tetrâmeras, botões florais com cálice aberto e lobos caliciniais distintos; hipanto não elevado acima do ápice do ovário; ovário bilocular, com mais de 4 óvulos por lóculo. Fruto bacáceo, com lobos caliciniais persistentes; sementes 1-2; embrião eugenióide, globoso a reniforme, cotilédones unidos ou individualizados, eixo hipocótilo-radícula visível ou não.

Embora o número total de espécies para Eugenia seja incerto, devido aos vários problemas nomenclaturais, é notório que o gênero é um dos maiores na família. Segundo McVaugh (1968), ao gênero estão subordinadas mais de 500 espécies que ocorrem na América do Sul. Landrum \& Kawasaki (1997) calculam cerca de 350 espécies para o Brasil; na Restinga da Marambaia ocorrem 13 espécies.

1.1. Eugenia bahiensis DC., Prodr. 3: 271. 1828.

Tipo: Brasiliae prov. Bahiensi, in silvis opacis, Martius s.n., s.d. (foto do holótipo M!).

Fig. 2-6

Arbusto a arvoreta de até 6 metros de altura, ramos novos, folhas novas, pecíolos, inflorescência, flores e frutos curto-velutinos; tronco com casca externa áspera. Folhas elípticas ou raro oblongas, ápice obtuso-acuminado, base cuneada, bordo ondulado e revoluto, cartáceas a coriáceas, discolores; 40-100× 20-55 mm; nervura principal sulcada na face adaxial e saliente na abaxial; nervuras secundárias 5-8 pares visíveis em ambas as faces; nervura marginal 1-4 mm do bordo; nervura intramarginal 0,2-1 $\mathrm{mm}$ do bordo, às vezes quase inconspícua; pecíolo 5-8 mm compr. Fascículos axilares em nós folhosos basais ou áfilos, com até 6 flores, eixo com 1-6 mm compr.; ferofilos ovados, ca. $1 \mathrm{~mm}$ compr., ciliados; antopódio 7-12 mm compr.; profilos triangulares, não conados, $1 \mathrm{~mm}$ compr., ciliados, decíduos. Botões florais obovados, até $7 \times 5 \mathrm{~mm}$; hipanto com ovário e cálice diferenciados; cálice ocultando o globo petalífero; lobos do cálice suborbiculares ou arredondados, $3-5 \times 4-5 \mathrm{~mm}$, desiguais 


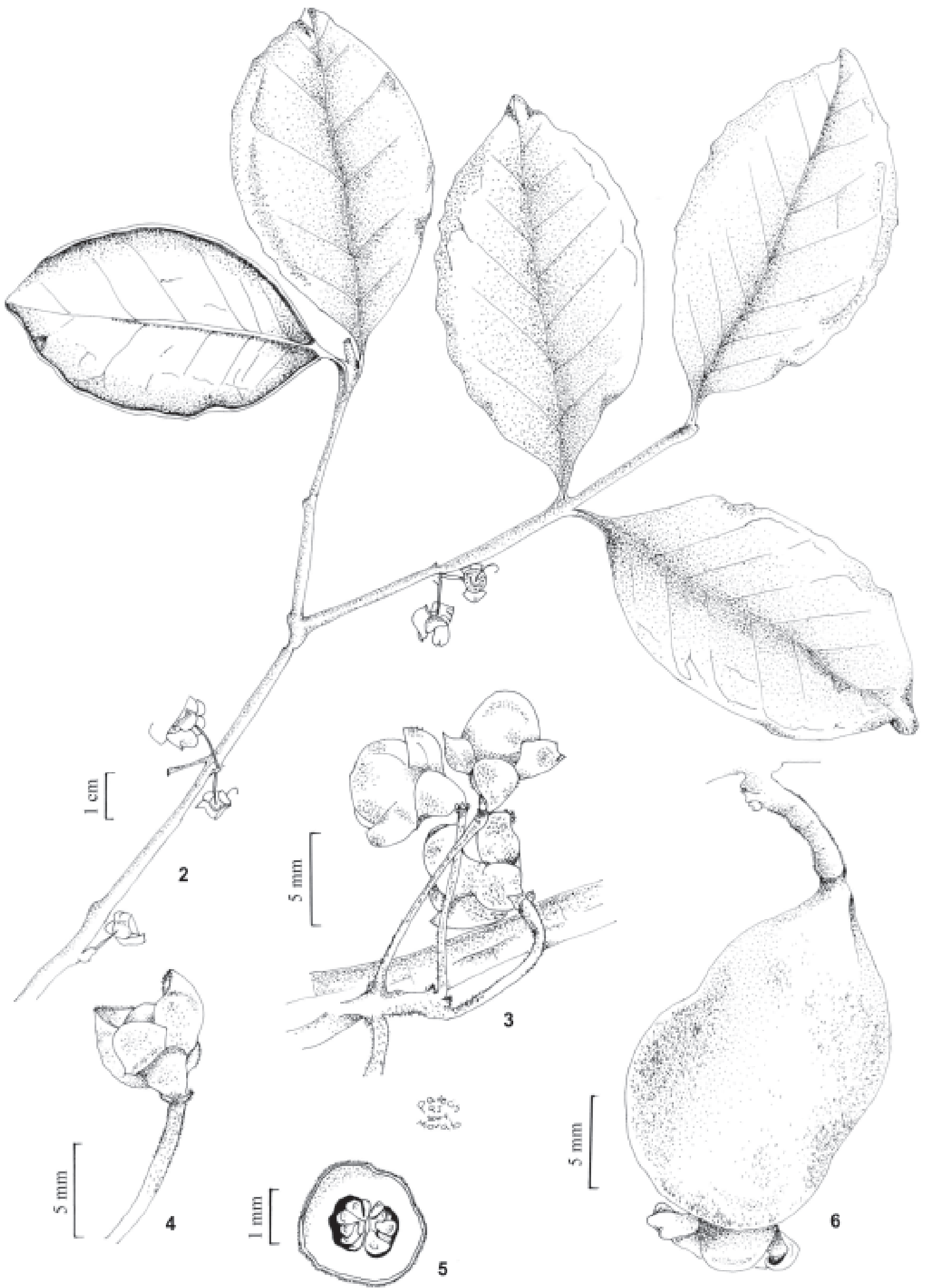

Figuras 2-6. Eugenia bahiensis DC.: 2. Ramo (Souza 189). 3. Inflorescência em fascículo. 4. Botão floral. 5. Corte transversal do ovário (Souza 254). 6. Fruto (Menezes 301). 
com 2 menores externos e 2 maiores internos, ciliados. Fruto globoso ou obovado, com até $20 \times 12 \mathrm{~mm}$, atropurpúreo quando maduro.

Distribuição geográfica: Bahia, Espírito Santo e Rio de Janeiro. No Rio de Janeiro ocorre na Floresta Pluvial Atlântica e na Restinga, nas seguintes localidades: Reserva da Praia do Sul, Marambaia, Jacarepaguá, Maricá, Cabo Frio, Macaé e São João da Barra. Na Restinga da Marambaia foi encontrada na formação arbustiva fechada de cordão arenoso e na floresta de cordão arenoso.

Floração: de outubro a março. Frutificação: de março a maio.

Comentário: espécie muito característica pela presença do indumento curto-velutino nos ramos novos, nas flores e nos frutos.

Material examinado: BRASIL. Rio de Janeiro: Mangaratiba, Restinga da Marambaia, Praia da Armação, 4/I/1999, fl., Menezes 196 (RBR); 29/IV/1999, fr., Menezes 301 (RBR); 18/III/2000, fl., Menezes 639 (RBR); 8/IV/2000, fr., Menezes 671 (RBR); 20/I/2001, fl., Souza 166 (RBR). Rio de Janeiro, Restinga da Marambaia, floresta de duna, 27/I/2001, fl., Souza 189 (RBR); 21/IV/2001, fr., Souza 200 (RBR).

1.2. Eugenia brasiliensis Lam., Encycl. 3: 203. 1789.

Tipo: Brasil, Jussieu s.n., s.d. (foto do holótipo P!).

Fig. 27-30

Arvoreta de até 6 metros de altura, glabra; tronco com casca externa laminada desfolhando em lâminas papiráceas. Folhas obovadas ou oblongas, ápice obtusoacuminado, base cuneada a decurrente, bordo revoluto, coriáceas, discolores, densamente pontuadas; 70-130×25-60 mm; nervura principal sulcada na face adaxial, saliente na abaxial; nervuras secundárias de difícil distinção com as intersecundárias; nervura marginal 2-3 mm do bordo; pecíolo 8-13 mm compr. Flores em racemo "stenocalyx", axilares terminais ou em nós folhosos basais, com invóluco de ferofilos envolvendo a gema floral, raque $20-40 \mathrm{~mm}$ compr., 3-4 pares de flores; ferofilos ovados a obovados, 3-5×3-6 mm compr., seríceos a glabrescentes, ciliados; antopódio 20-45 mm compr.; profilos ovados, não conados, 1-2 mm compr., ciliados, decíduos. Botões florais globosos ou piriformes, $8-10 \times 5-6 \mathrm{~mm}$, hipanto com ovário e cálice diferenciados; cálice ocultando parcialmente o globo petalífero; lobos do cálice oblongos, 5-7×2-3 mm, iguais, ciliados. Fruto globoso, 13-20 mm diâm., atropurpúreo quando maduro.
Distribuição geográfica: em toda a faixa litorânea oriental do Brasil, desde os Estados do nordeste até Santa Catarina (Legrand \& Klein 1969). No Rio de Janeiro ocorre na Floresta Pluvial Atlântica e na Restinga, nas seguintes áreas: Reserva da Praia do Sul, Marambaia e Jacarepaguá. Na Restinga da Marambaia foi encontrada na floresta inundável e na floresta de cordão arenoso.

Floração: de julho a fevereiro. Frutificação: de outubro a fevereiro.

Comentário: espécie muito cultivada em virtude dos seus frutos comestíveis.

Nome comum: grumixama.

Material examinado: BRASIL. Rio de Janeiro: Mangaratiba, Restinga da Marambaia, Praia da Armação, 18/III/2000, vg., Menezes 632 (RBR); 29/I/2002, fr., Menezes 914 (RBR). Rio de Janeiro, Jardim Botânico do Rio de Janeiro (cultivado), 1932, fl., Kuhlmann s.n. (RB); Parque Nacional da Tijuca, 26/IX/1979, fl., Lima 1103 (RB).

1.3. Eugenia copacabanensis Kiaersk., Enum. Myrt. bras.: 172.1893.

Tipo: ad Copacabana, Glaziou 3982, II-1870 (isótipo $\mathrm{R}$ !).

Fig. 7-11

Arbusto a arvoreta de até 6 metros de altura, glabra; tronco com casca externa laminada desfolhando em lâminas papiráceas. Folhas elípticas, ovadas ou lanceoladas, ápice acuminado, base cuneada a decurrente, bordo foliar revoluto com um espessamento amarelado, coriáceas, discolores, com a face adaxial brilhante, densamente pontuada; 40-70×20-35 mm; nervura principal saliente em ambas as faces; nervuras secundárias 8-10 pares visíveis em ambas as faces; nervura marginal 1-2 mm do bordo; pecíolo 8-12 mm compr., amarelado no material vivo. Fascículos axilares em nós folhosos basais, com 4-6 flores, raque 3-5 mm compr.; ferofilos ovados, ca. $1 \mathrm{~mm}$ compr., ciliados; antopódio 5-7 mm compr.; profilos ovados, não conados, ca. $1 \mathrm{~mm}$ compr., ciliados, decíduos. Botões florais obovados, 4-6×3 mm, hipanto com ovário e cálice diferenciados; cálice não ocultando o globo petalífero; lobos do cálice ovado-arredondados, 2-3×2-3 mm compr., iguais, ciliados. Fruto piriforme, 30-40× 20-25 mm, amarelo-alaranjado quando maduro.

Distribuição geográfica: ocorre apenas nas restingas do Rio de Janeiro, nas seguintes áreas: Reserva da Praia do Sul, Marambaia, Jacarepaguá, Maricá e Cabo Frio. Na Restinga da Marambaia foi 
encontrada na formação herbácea fechada de cordão arenoso, na arbustiva aberta não inundável, na arbustiva fechada de cordão arenoso, na arbustiva fechada de pós-praia e na floresta de cordão arenoso.

Floração: de janeiro a junho. Frutificação: registrada em todos os meses do ano.

Comentário: espécie muito característica por suas folhas brilhantes, com margens e pecíolos amarelados na planta viva. Sua fase de frutificação persiste por quase todo o ano devido ao longo tempo de desenvolvimento dos frutos até a maturação.

Material examinado: BRASIL. Rio de Janeiro: Mangaratiba, Restinga da Marambaia, Praia da Armação, 29/V/1999, fr., Menezes 291 (RBR); 20/I/2001, fl., Souza 170 (RBR); 27/XII/2002, fl., Souza 252 (RBR); 22/II/2003, fl., Menezes 1061 (RBR); 31/X/2003, fr., Souza 291 (RBR). Rio de Janeiro, Restinga da Marambaia, formação de Palmae, 30/XII/1994, fl., Menezes 157 (RBR); formação arbustiva fechada, 20/X/1995, fr., Menezes 160 (RBR); 9/III/2002, fl., Souza 240 (RBR); 20/XII/2003, fl., Souza 299 (RBR); floresta de duna, 3/VII/1998, fr., Souza 27 (RBR); 9/I/1999, fl., Souza 38 (RBR); 15/I/1999, fl., Souza 66 (RBR); 8/V/1999, fr., Souza 111 (RBR).

1.4. Eugenia excelsa O. Berg, Fl. bras. 14(1): 277. 1857.

Tipo: Habitat in silvis primaevis prov. Rio de Janeiro, Sellow s.n., s.d. (holótipo B; foto do isótipo G!, U!, K!).

Fig. 12-17

Arvoreta de até 9 metros de altura, glabra; tronco com casca externa áspera. Folhas ovadas, obovadas ou elípticas, ápice longo acuminado, base cuneada, bordo foliar revoluto, coriáceas, discolores, pontuações não muito evidentes em ambas as faces, face adaxial opaca e rugosa; $50-100 \times 25-50 \mathrm{~mm}$; nervura principal saliente ou plana na face adaxial e saliente na abaxial; nervuras secundárias 8-12 pares pouco visíveis na face adaxial e evidentes na abaxial; nervura marginal 1-3 mm do bordo; pecíolo 5-7 mm compr. Fascículos axilares em nós folhosos basais ou áfilos, com 4-6 flores, eixo com 2-3 mm compr.; ferofilos oblongos, 1,5-2 mm compr., ciliados; antopódio 5-20 mm compr.; profilos suborbiculares ou arredondados, não conados, até ca. $1 \mathrm{~mm}$ compr., decíduos. Botões florais obovados, $3 \times 3 \mathrm{~mm}$, hipanto com ovário e cálice diferenciados; cálice ocultando o globo petalífero; lobos do cálice ovados, 2-3×1,5-2 mm compr., iguais entre si, ciliados. Fruto globoso, até $7 \mathrm{~mm}$ diâm., enegrecido quando maduro.

Distribuição geográfica: Pernambuco, Bahia, Espírito Santo, Rio de Janeiro, São Paulo e Santa Catarina, ocorrendo em Floresta Pluvial Atlântica e em Restinga. Nas restingas do Rio de Janeiro distribui-se pelas seguintes áreas: Reserva da Praia do Sul, Marambaia, Jacarepaguá, Maricá, Cabo Frio e Macaé. Na Restinga da Marambaia foi encontrada na formação arbustiva fechada de cordão arenoso, na arbustiva fechada de pós-praia e na floresta de cordão arenoso.

Floração: de julho a outubro. Frutificação: de setembro a dezembro.

Comentário: espécie característica por apresentar a superfície adaxial da folha opaca e rugosa após herborizada.

Material examinado: BRASIL. Rio de Janeiro: Mangaratiba, Restinga da Marambaia, floresta de restinga, 24/X/1999, fl., Menezes s.n. (RBR); área da Aeronáutica, 3/I/2002, fl., Menezes 887 (RBR). Rio de Janeiro, Restinga da Marambaia, floresta de duna, 6/I/1997, fl., Menezes s.n. (RBR); 29/XI/1999, fr., Souza 135 (RBR); 20/X/2000, fl., Souza 138 (RBR); 7/XI/2000, fl., Melo 10 (RBR); 21/IV/2001, fl., Souza 202 (RBR); 27/IX/2003, fl., Souza 267 (RBR); Restinga de Jacarepaguá, 23/IX/1969, fr., Sucre 5958 (RB).

1.5. Eugenia neonitida Sobral, Napaea 11: 36. 1995.

Eugenia nitida Cambess., Fl. Bras. Merid. 2: 349. 1832.

Tipo: In dumetis terrae linguae vulgò Restinga inter lacum Araruàma et Oceanum excurrentis prope civitatem Cabo Frio in provincia Rio de Janeiro, Saint-Hilaire s.n., s.d. (foto do holótipo P!).

Fig. 18-23

Arbusto de até 2 metros de altura, com indumento brúneo-ferrugíneo-tomentoso, principalmente nas porções jovens dos ramos, folhas e flores; tronco com casca externa áspera e desprendendo-se em placas. Folhas elípticas, ápice curto obtuso-acuminado; base obtusa ou arredondada, bordo revoluto, membranáceas a coriáceas, densamente translúcido-pontuadas, discolores, face adaxial nítida; 20-55×10-27 mm; nervura principal sulcada na face adaxial e saliente na abaxial; nervuras secundárias 8-10 pares, evidentes e salientes nas faces abaxial e adaxial; nervura marginal 1-2 mm do bordo; pecíolo 1-2 mm compr. Racemos "stenocalyx" axilares terminais, raque até $5 \mathrm{~mm}$, com 1-2 pares de flores; ferofilos elíptico-ovados, 
2-4×1-2 mm, na base do antopódio, decíduos; antopódio 3-12 mm compr.; profilos elípticos ou ovados, não conados, 3-4×3-4 mm, ocultando o ovário, persistentes ou não no fruto jovem. Botões florais globosos, até $8 \times 8 \mathrm{~mm}$, hipanto com ovário e cálice diferenciados; cálice ocultando o globo petalífero; lobos do cálice elípticos, ovados ou oblongos, foliáceos, ultrapassando o globo petalífero, 7-8×3-4 mm, iguais; ovário oculto pelos profilos, 8-costado longitudinalmente. Fruto globoso, costado longitudinalmente, até $40 \mathrm{~mm}$ diâm., amarelo quando maduro.

Distribuição geográfica: ocorre nas restingas do Espírito Santo e Rio de Janeiro, onde se distribui nas áreas: Marambaia, Grumari, Jacarepaguá, Maricá, Cabo Frio, Barra de São João e Macaé. Na Restinga da Marambaia foi encontrada na formação herbácea fechada de cordão arenoso, na arbustiva aberta não inundável, na arbustiva fechada de cordão arenoso e na arbustiva fechada de pós-praia.

Floração: de setembro a fevereiro. Frutificação: de outubro a março.

Comentário: a espécie apresenta um fruto muito característico, costado longitudinalmente, amarelo quando maduro, e de tamanho que pode atingir $4 \mathrm{~cm}$ diâm. É um dos maiores frutos de Myrtaceae da Marambaia, conhecido também pelo odor adocicado e de sabor agradável, popularmente apreciado na alimentação ou no preparo de bebidas.

Nome comum: pitangão, pitangatuba.

Material examinado: BRASIL. Rio de Janeiro: Mangaratiba, Restinga da Marambaia, área da Aeronáutica, 3/I/2002, fl., Menezes 877 (RBR); área de moitas, 15/XI/2002, fl., Menezes 1080 (RBR). Rio de Janeiro, Restinga da Marambaia, floresta de duna, 3/III/1998, fl., Menezes s.n. (RBR); 13/IX/2000, fl., Menezes 459 (RBR); 20/X/2000, fl., Souza 141 (RBR); 27/IX/2003, fl., Souza 269 (RBR); 25/X/2003, fl., fr., Souza 284 (RBR).

1.6. Eugenia neosilvestris Sobral, Napaea 11: 36. 1995.

Stenocalyx silvestris O. Berg, Fl. Bras. 14(1): 346. 1857.

Tipo: Habitat ad Cabo Frio in prov. Rio de Janeiro, floret septembri: Princ. de Neuwied s.n., s.d. (foto do tipo BR!).

Fig. 24-26

Arbusto a arvoreta de até 5 metros de altura, com ramos novos, pecíolos, face abaxial das folhas e também a adaxial quando novas, antopódio, flores e ovário ferrugíneo-pubescentes a vilosas; tronco com casca externa laminada desfoliante em lâminas papiráceas. Folhas elípticas ou oval-oblongas, ápice obtuso-acuminado, obtuso ou arredondado, base cuneada, às vezes um pouco decurrente ou arredondada, bordo revoluto, coriáceas, densamente pontuadas; $23-75 \times 11-40 \mathrm{~mm}$; nervura principal sulcada na face adaxial e saliente na abaxial; nervuras secundárias pouco distintas das intersecundárias; nervura marginal 1-2 mm do bordo; pecíolo 1-5 mm compr. Flores em racemos "stenocalyx", axilares terminais ou em nós folhosos basais, com invólucro de ferofilos envolvendo a gema floral, raque 3-13 mm compr., 2-3 pares de flores; ferofilos na base do invólucro ovados e na base do antopódio oblongos ou espatulados, 3-7×2-4 mm, ciliados; antopódio 5-30 mm compr.; profilos ovados ou triangulares, não conados, ca. $1 \mathrm{~mm}$ compr., decíduos. Botões florais globosos a piriformes, $4 \mathrm{~mm}$ compr., com cálice ocultando o globo petalífero; lobos do cálice oblongos, 3-6×2-3 mm, ciliados; hipanto com ovário e cálice diferenciados, ócreo-pubescente ou viloso. Fruto não visto.

Distribuição geográfica: ocorre desde o Rio de Janeiro até Santa Catarina, limitada à zona litorânea (Legrand \& Klein 1969). No Rio de Janeiro foi encontrada nas seguintes áreas de restinga: Marambaia e Cabo Frio. Na Restinga da Marambaia só foi registrada a sua ocorrência na floresta inundável.

Floração: de setembro a dezembro. Frutificação: não observada.

Comentário: espécie muito semelhante a Eugenia brasiliensis Lam., distinguindo-se por apresentar folhas, inflorescências e flores menores e pela pilosidade ferrugínea nos ramos novos, folhas novas e flores. Legrand \& Klein (1969) observaram que na flora de Santa Catarina o hábitat preferencial da espécie é em solos úmidos de planícies quaternárias. Tal observação foi registrada também para a Restinga da Marambaia, onde a única formação em que foi encontrada é caracterizada pela inundação periódica.

Nome comum: grumixana-miúda.

Material examinado: BRASIL. Rio de Janeiro: Búzios, Praia da Gorda, 18/VIII/1998, fl., Lobão 336 (RB). Mangaratiba, Restinga da Marambaia, borda da Lagoa Vermelha, 27/XII/2002, fl., Menezes 1029 (RBR).

1.7. Eugenia oxyoentophylla Kiaersk., Enum. Myrt. bras.: 145. 1893.

Tipo: Sem localidade, Glaziou 6832, s.d. (isótipo R!). Fig. 57-60 


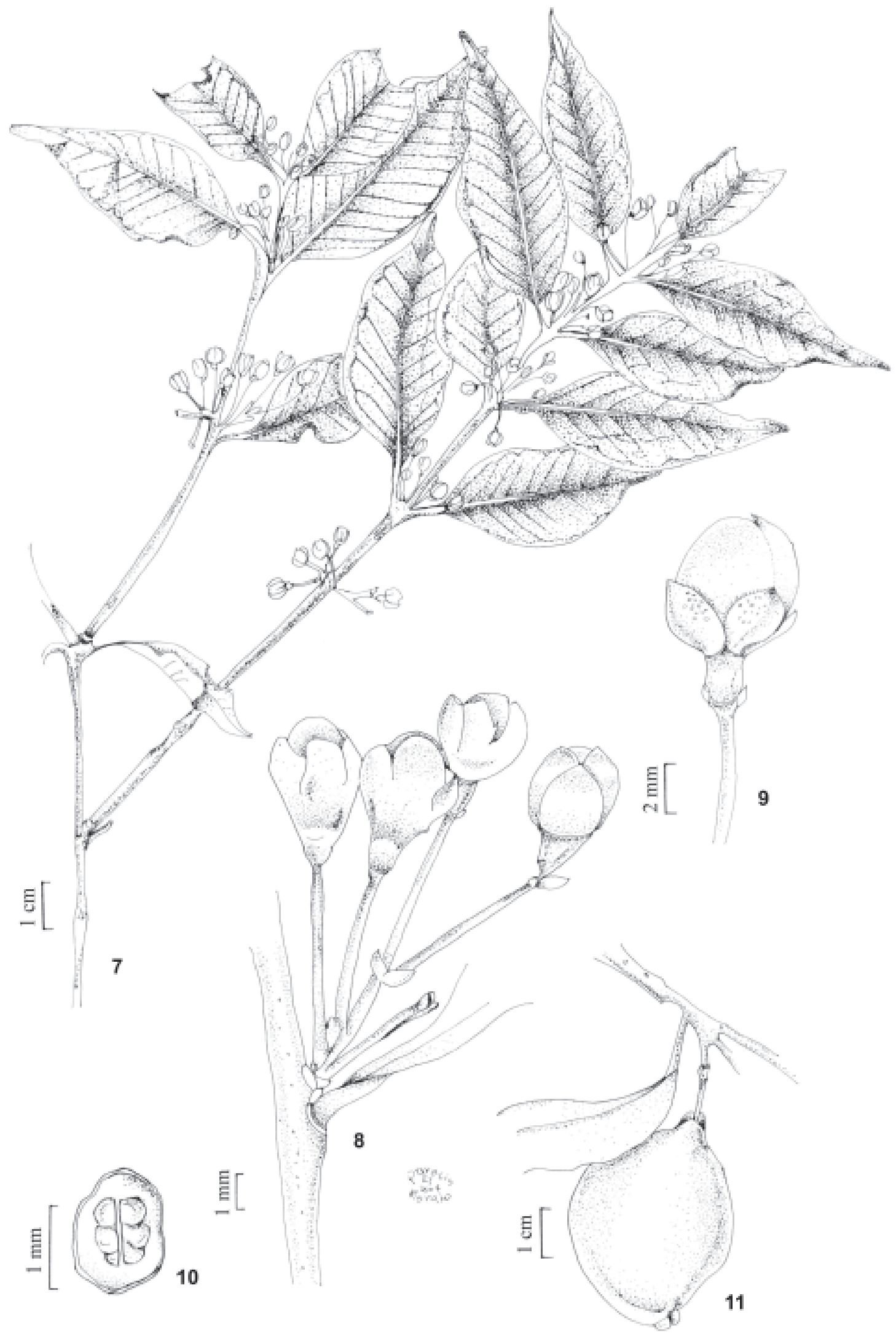

Figuras 7-11. Eugenia copacabanensis Kiaersk.: 7. Ramo. 8. Inflorescência em fascículo. 9. Botão floral. 10. Corte transversal do ovário (Souza 38). 11. Fruto (Souza 291). 


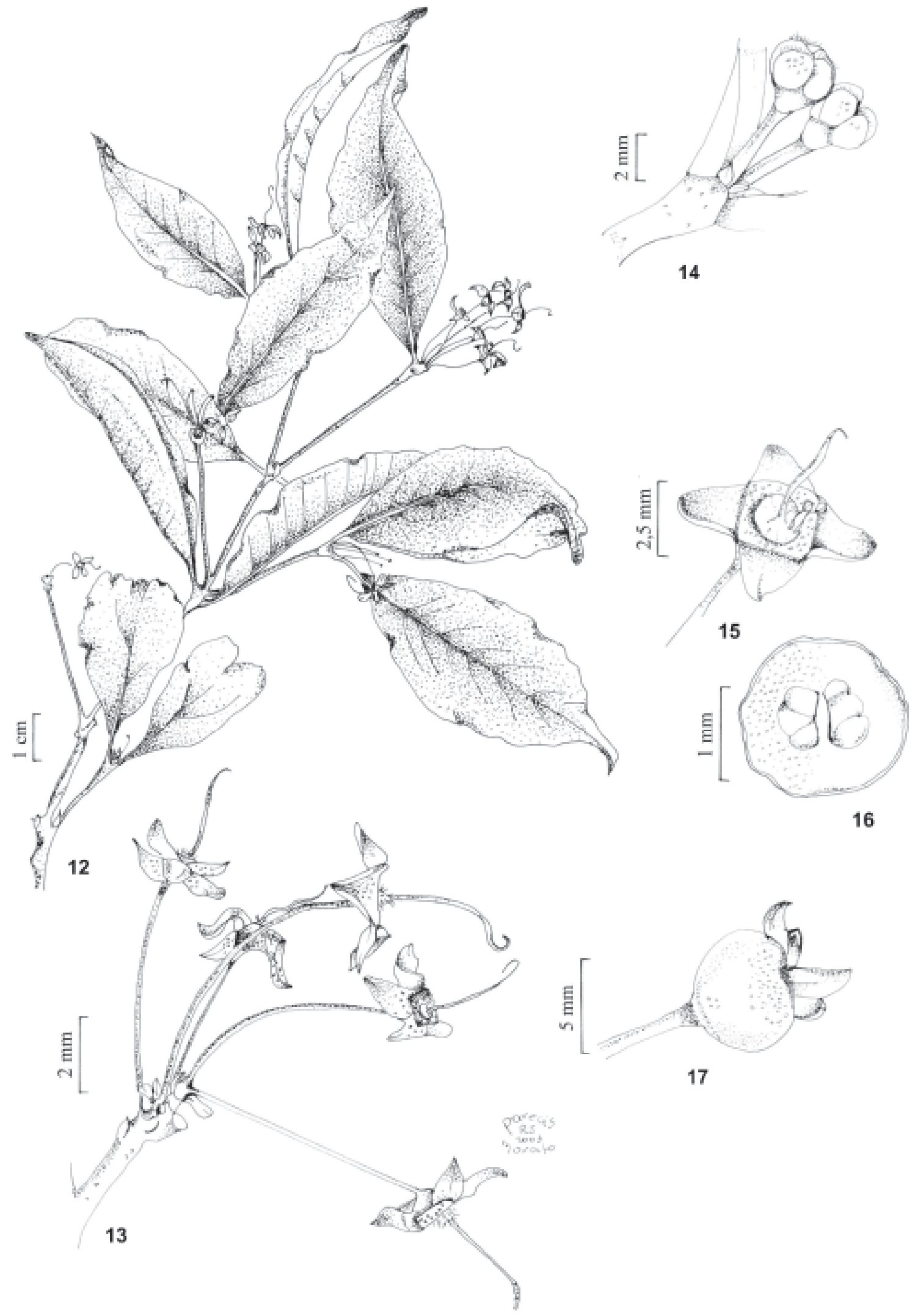

Figuras 12-17. Eugenia excelsa O. Berg: 12. Ramo. 13. Inflorescência em fascículo. 14. Botões florais. 15. Flor após antese. 16. Corte transversal do ovário (Souza 267). 17. Fruto (Sucre 5958). 


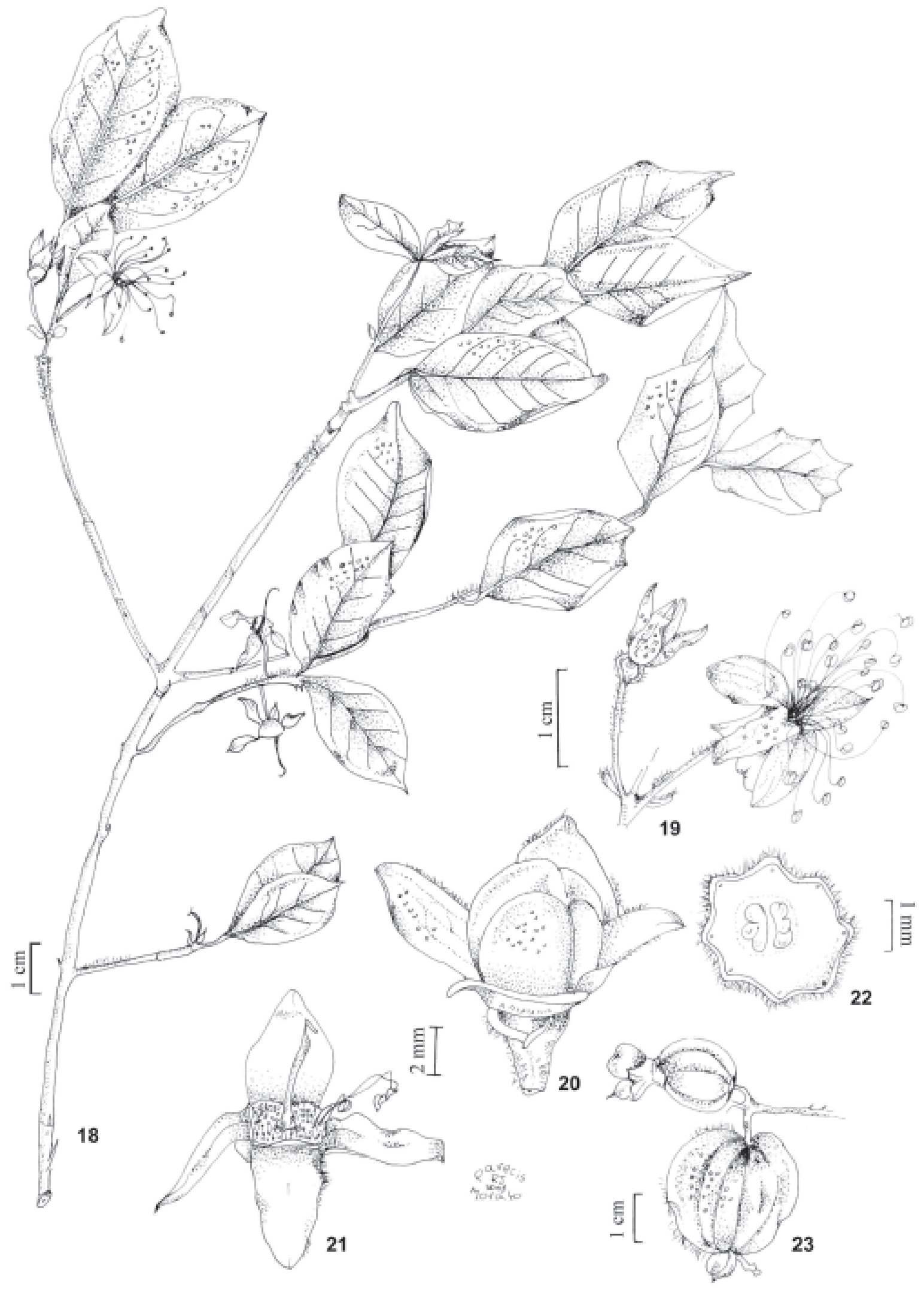

Figuras 18-23. Eugenia neonitida Sobral: 18. Ramo. 19. Inflorescência em racemo“stenocalyx" (Menezes s.n.). 20. Botão floral. 21. Flor após antese. 22. Corte transversal do ovário (Souza 269). 23. Frutos (Souza 284). 


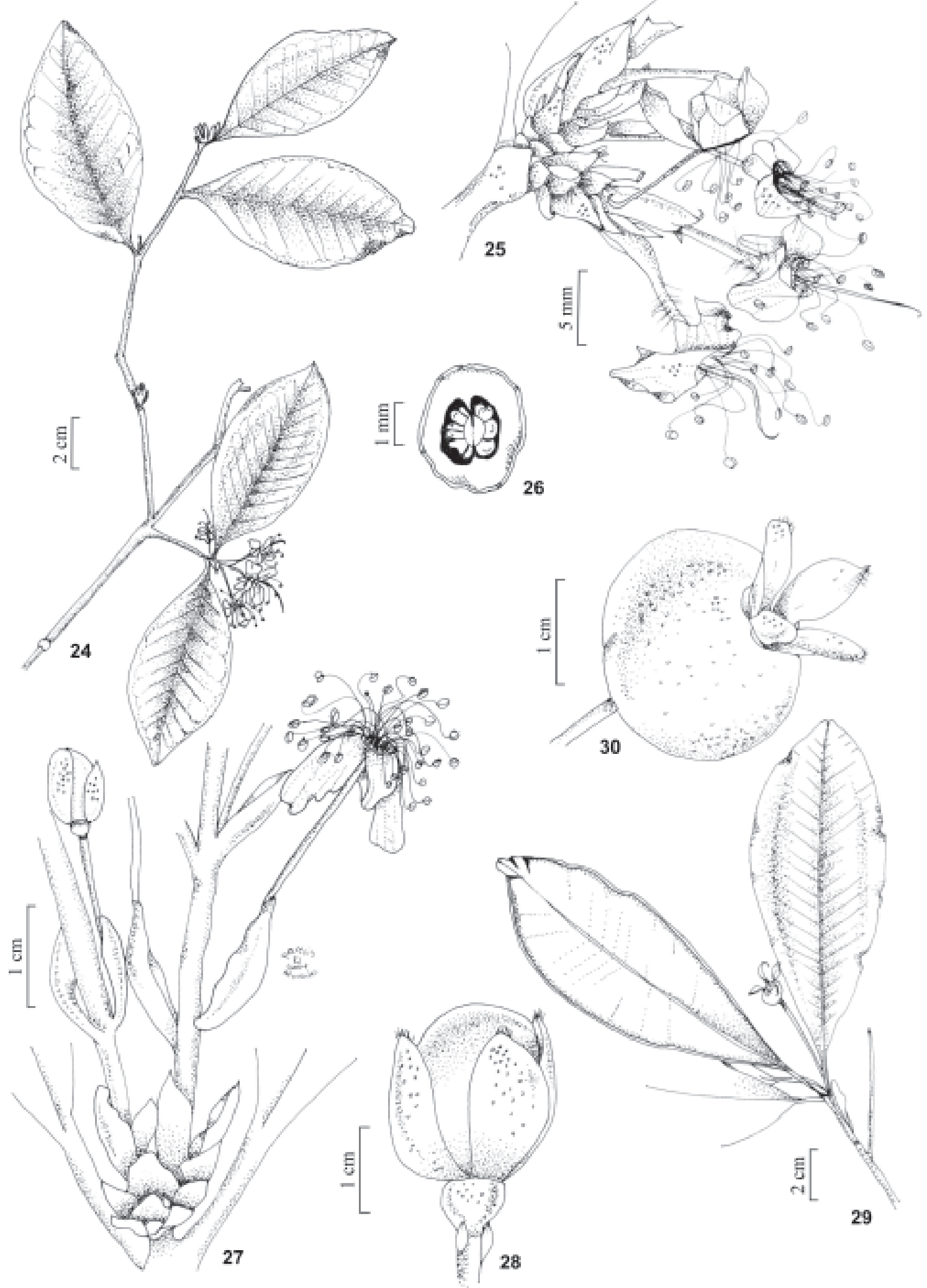

Figuras 24-26. Eugenia neosilvestris Sobral: 24. Ramo. 25. Inflorescência em racemo"stenocalyx". 26. Corte transversal do ovário (Menezes 1029). Figuras 27-30. Eugenia brasiliensis Lam.: 27. Inflorescência em racemo“stenocalyx”. 28. Botão floral (Lima 1103). 29. Ramo. 30. Fruto (Menezes 914). 
Arvoreta de até 8 metros de altura, glabra ou glabrescente, com ramos novos, folhas novas, pecíolos e inflorescências hialino-pubérulos; tronco com casca externa áspera e desprendendo-se em placas. Folhas elípticas ou lanceoladas, ápice longamente acuminado, base cuneada, bordo foliar ondulado e às vezes um pouco revoluto, cartáceas a coriáceas, discolores, pontuações não visíveis a olho nu, superfície ondulada; $35-70 \times 10-35 \mathrm{~mm}$; nervura principal sulcada na face adaxial e saliente na abaxial; nervuras secundárias 6-10 pares pouco evidentes ou invisíveis em ambas as faces; nervura marginal 1-2 mm do bordo; pecíolo 3-7 mm compr. Fascículos axilares terminais ou em nós folhosos basais, com 4-6 flores, raque 6-7 mm compr.; ferofilos triangulares, ca. $1 \mathrm{~mm}$ compr., ciliados; antopódio ca. $1 \mathrm{~mm}$ compr.; profilos triangulares, conados, ca. 1 mm compr., ciliados, ocultando o ovário, persistentes na antese até o fruto. Botões florais globosos, $3 \mathrm{~mm}$ diâm.; cálice ocultando o globo petalífero; lobos do cálice arredondados ou suborbiculares, $1-2 \times 2 \mathrm{~mm}$ compr., desiguais, com 2 maiores externos e 2 menores internos, ciliados. Fruto bacáceo globoso, 5-7 mm diâm., vermelho quando maduro.

Distribuição geográfica: ocorre apenas nas restingas do Rio de Janeiro, nas seguintes áreas: Marambaia, Grumari e Maricá. Na Restinga da Marambaia foi encontrada na formação arbustiva fechada de cordão arenoso.

Floração: julho e novembro. Frutificação: de janeiro a abril.

Comentário: espécie afim de Eugenia repanda O. Berg, distinguindo-se pela folha longamente acuminada e com a nervação mais inconspícua.

Material examinado: BRASIL. Rio de Janeiro: Mangaratiba, Ilha da Marambaia, Praia do Caju, 1/IV/2000, fr., Menezes 521 (RBR). Rio de Janeiro, Restinga da Marambaia, floresta de duna, 13/VII/1998, fl., Menezes 630 (RBR); 9/V/2001, vg., Souza 205 (RBR).

\subsection{Eugenia punicifolia (Kunth) DC., Prodr. 3: 267.} 1828 .

Basiônimo: Myrtus punicifolia Kunth, Nov. Gen. Sp. 6: 149.1823.

Tipo: Venezuela, Humboldt \& Bonpland 273, s.d. (foto do tipo P!).

Fig. 31-35

Arbusto a arvoreta de até 8 metros de altura, com ramos novos, folhas novas e flores glabras ou esparsopubérulas; tronco com casca externa áspera. Folhas elípticas ou obovadas, ápice curto-obtuso-acuminado, base cuneada ou aguda, bordo revoluto, cartáceas a coriáceas, discolores, pontuações não visíveis a olho $\mathrm{nu} ; 20-100 \times 10-65 \mathrm{~mm}$; nervura principal sulcada na face adaxial e saliente na abaxial; nervuras secundárias 6-8 pares visíveis em ambas as faces; nervura marginal 1-3 mm do bordo; pecíolo 2-5 mm compr. Fascículos axilares em nós folhosos basais, com 2-4 flores, eixo ca. $2 \mathrm{~mm}$ compr.; ferofilos ovados e arredondados, ca. $1 \mathrm{~mm}$ compr.; antopódio 3-20 mm compr.; profilos triangulares, ca. $1 \mathrm{~mm}$ compr., não conados, persistentes na antese. Botões florais obovados, 4-5×3-4 mm, hipanto com ovário e cálice diferenciados; cálice ocultando o globo petalífero; lobos do cálice ovadoarredondados ou oblongos, 1-3×2 mm, desiguais, com 2 menores externos e 2 maiores internos, ciliados. Fruto bacáceo globoso ou elipsóide, até $10 \mathrm{~mm}$ diâm., vermelho quando maduro.

Distribuição geográfica: distribui-se por quase todo o Brasil, Paraguai e Venezuela (Sobral 1987), ocorrendo em diversas fitofisionomias. Nas restingas do Rio de Janeiro ocorre nas seguintes áreas: Reserva da Praia do Sul, Marambaia, Grumari, Jacarepaguá, Maricá, Cabo Frio, Barra de São João, Macaé e São João da Barra. Na Restinga da Marambaia foi encontrada na formação herbácea fechada de cordão arenoso, na arbustiva aberta não inundável, na arbustiva fechada de cordão arenoso, na arbustiva fechada de pós-praia, floresta de cordão arenoso.

Floração: de junho a março. Frutificação: de novembro a fevereiro.

Comentário: a espécie apresenta uma grande variação morfológica foliar, o que acarretou numa grande lista de sinônimos (McVaugh 1969; Sobral 1987). É muito comum e abundante nas restingas do Estado do Rio de Janeiro com uma grande representatividade nas coleções de herbários, onde freqüentemente é identificada como Eugenia ovalifolia Cambess., um sinônimo.

Material examinado: BRASIL. Rio de Janeiro: Mangaratiba, Restinga da Marambaia, Praia da Armação, 5/V/2001, fl., Menezes s.n. (RBR); 22/XI/1999, fr., Menezes 650 (RBR); 16/II/2000, fr., Menezes 327 (RBR); 22/XII/1998, fr., Menezes s.n. (RBR). Rio de Janeiro, Restinga da Marambaia, floresta de duna, 3/VII/1998, fl., Souza 28 (RBR); 29/XI/1999, fr., Souza 134 (RBR); Restinga de Jacarepaguá, 4/VIII/1958, fl., Pereira 4108 (RB).

1.9. Eugenia rostrata O. Berg, Fl. bras. 14(1): 282. 1857.

Tipo: Brasil, Sellow s.n., s.d. (B).

Fig. 36-40 
Arvoreta de até 8 metros de altura, glabra ou glabrescente, com ramos novos e ferofilos pubescentes a seríceos; tronco com casca externa laminada desfoliante em placas rígidas, deixando um aspecto liso, esbranquiçado ou malhado. Folhas lanceoladas, elípticas ou oblongas, ápice longoacuminado; base cuneada, bordo revoluto, coriáceas, discolores, com pontuações não evidentes; 40-90× 13-40 mm; nervura principal sulcada na face adaxial e saliente na abaxial; nervuras secundárias tênues a imperceptíveis em ambas as faces; nervura marginal 1-3 mm do bordo; pecíolo 3-10 mm compr. Fascículos axilares em nós folhosos basais ou áfilos, com 4-6 flores, eixo com 2-3 mm compr.; ferofilos ovados, pubescentes, ca. $1 \mathrm{~mm}$ compr., ciliados; antopódio 5-10 mm compr.; profilos ovados, ca. $1 \mathrm{~mm}$ compr., não conados, ciliados, persistentes até o fruto. Botões florais obovados, 2-3×2-3 mm, hipanto com ovário e cálice diferenciados; cálice não ocultando o globo petalífero; lobos do cálice ovados a suborbiculares, 1-2×1-2 mm compr., desiguais com 2 menores externos e 2 maiores internos, ciliados. Fruto bacáceo globoso, 5-6 mm diâm.

Distribuição geográfica: sul da Bahia, Espírito Santo e Rio de Janeiro, em Floresta Pluvial Atlântica e Restinga, onde se distribui nas seguintes áreas: Marambaia, Jacarepaguá e Cabo Frio. Na Restinga da Marambaia foi encontrada na formação arbustiva fechada de cordão arenoso e na floresta de cordão arenoso.

Floração: de outubro a abril. Frutificação: outubro e novembro.

Comentário: Eugenia rostrata apresenta o tronco com casca laminada, que se desprende em placas e assume um aspecto liso, de coloração esbranquiçada ou malhada; as folhas são longamente acuminadas, com nervação inconspícua em ambas as faces e nervura principal sulcada na face adaxial.

Material examinado: BRASIL. Rio de Janeiro: Mangaratiba, Restinga da Marambaia, Praia da Armação, 24/X/1999, fl., Menezes s.n. (RBR); 24/X/1999, fl., Menezes 510 (RBR); área da Aeronáutica, 3/I/2002, fl., Menezes 884 (RBR). Rio de Janeiro, Restinga da Marambaia, floresta de duna, 3/VII/1998, fl., Souza 24 (RBR); 2/VII/1999, fl., Souza 126 (RBR); 27/V/2000, fr., Melo 01 (RBR). Saquarema, Reserva de Jacarepiá, 22/XI/1996, fr., Farney 3556 (RB).

1.10. Eugenia rotundifolia Casar., Nov. stirp. bras. 40. 1842 .
Tipo: In arenosis maritimis inter Copacabana et Lagoa de Rodrigo de Freytas prope Rio de Janeiro, Casaretto 1201, VIII/1839 (foto do tipo G!). Fig. 41-45

Arbusto até 2 metros de altura. Planta glabra; tronco com casca externa áspera. Folhas elípticas obovadas ou suborbiculadas, ápice arredondado, obtuso ou curto-obtuso-acuminado; base arredondada, obtusa ou aguda, bordo revoluto, coriáceas, discolores, densamente pontuadas; $35-75 \times 20-55 \mathrm{~mm}$; nervura principal plana ou sulcada na face adaxial e saliente na abaxial; nervuras secundárias 6-10 pares visíveis em ambas as faces; nervura marginal 2-4 $\mathrm{mm}$ do bordo; pecíolo 2-5 mm compr., não amarelado no material vivo. Fascículos axilares em nós folhosos basais ou áfilos, com 4-6 flores, raque com ca. 2 mm compr.; ferofilos arredondados, ca. 0,5 mm compr., ciliados; antopódio 5-10 mm compr.; profilos arredondados, ca. $1 \mathrm{~mm}$ compr., não conados, ciliados, persistentes até o fruto. Botões florais globosos, até $4 \mathrm{~mm}$ diâm., hipanto com ovário e cálice diferenciados, densamente pontuados; cálice não ocultando o globo petalífero; lobos do cálice arredondados, muito reduzidos com ca. $1 \mathrm{~mm}$ compr., ciliados. Fruto bacáceo globoso ou elipsóide, até $15 \mathrm{~mm}$ diâm., enegrecido quando maduro.

Distribuição geográfica: Bahia, Espírito Santo, São Paulo e Rio de Janeiro. No Rio de Janeiro, distribui-se pelas seguintes áreas de restinga: Marambaia, Grumari, Jacarepaguá, Maricá, Cabo Frio, Macaé e São João da Barra. Na Restinga da Marambaia foi encontrada na formação herbácea fechada de cordão arenoso, na arbustiva aberta não inundável, na arbustiva fechada de cordão arenoso e na arbustiva fechada de pós-praia.

Floração: de fevereiro a junho. Frutificação: de abril a dezembro.

Comentário: os exemplares estudados de Eugenia rotundifolia mostraram que a espécie apresenta grande variação, principalmente em relação à morfologia foliar, o que foi observado nas coleções de herbários examinadas. Os limites entre E. rotundifolia, E. umbelliflora O. Berg e E. cassinoides O. Berg são imprecisos e tais binômios são freqüentemente encontrados como identificações de uma única espécie, o que evidencia a necessidade de futuros estudos para definições dos limites específicos. No presente trabalho optou-se por manter E. rotundifolia, binômio mais antigo.

Nome comum: araponga.

Material examinado: BRASIL. Rio de Janeiro: Mangaratiba, Restinga da Marambaia, Praia da 
Armação, complexo florestal inundável, 8/IV/2000, fl., Menezes 593 (RBR); área de moitas, 22/II/2003, fl., Menezes 1052 (RBR); 15/I/2004, fl., Souza 305 (RBR). Rio de Janeiro, Restinga da Marambaia, próximo a linha 2, 9/III/2002, fl., Souza 233 (RBR); Restinga de Jacarepaguá, Itaúna, 18/VIII/1975, fr., Araujo 752 (RB).

1.11. Eugenia sulcata Spring ex Mart., Flora 20(2): 85. 1837.

Tipo: In Serra dos Orgaons, Martius s.n., s.d. (M).

Fig. 46-51

Arbusto a arvoreta de até 4 metros de altura, com ramos e inflorescências jovens, esparso-pilosos a glabrescentes; tronco com casca externa laminada desfoliante em lâminas papiráceas. Folhas elípticas ou oblongas, ápice agudo ou acuminado, base cuneada ou raramente aguda, cartáceas, discolores, densamente pontuadas na face abaxial; $10-25 \times 20-50 \mathrm{~mm}$; nervura principal sulcada e saliente na abaxial; nervuras secundárias pouco evidentes em ambas as faces; nervura marginal inconspícua; pecíolo 2-5 mm compr. Flores em racemo "stenocalyx" axilares terminais ou em nós folhosos basais, raque 5-10 mm compr., 2-3 pares de flores; ferofilos oblongos a lineares, 1-4 mm compr., ciliados; antopódio 10-25 mm compr.; profilos oblongos, ca. $1 \mathrm{~mm}$ compr., não conados, ciliados, decíduos. Botões florais globosos ou piriformes, 3-5 mm diâm., hipanto com ovário 8-costado longitudinalmente, diferenciado do cálice; cálice ocultando parcialmente o globo petalífero; lobos do cálice oblongos, $4-5 \times 2-2,5 \mathrm{~mm}$, iguais, ciliados. Fruto bacáceo globoso ou piriforme, costado longitudinalmente, $6-12 \times 7-15 \mathrm{~mm}$, atropurpúreo e com lobos do cálice roxos quando maduro.

Distribuição geográfica: ocorre do Espirito Santo a Santa Catarina (Legrand \& Klein 1969), em Floresta Pluvial Atlântica e Restinga. Nas restingas do Rio de Janeiro distribui-se pelas seguintes áreas: Reserva da Praia do Sul, Marambaia, Jacarepaguá, Maricá, Cabo Frio, Barra de São João e Macaé. Na Restinga da Marambaia foi encontrada na formação arbustiva fechada de cordão arenoso e na floresta de cordão arenoso.

Floração: de julho a novembro. Frutificação: de setembro a dezembro.

Comentário: embora a espécie seja muito confundida nas coleções de herbário com Eugenia uniflora L., é distinta pelas folhas com nervação inconspícua, e também por seus frutos de menores dimensões e de coloração enegrecida, quando maduros. Os espécimes encontrados na Marambaia apresentaram-se sempre muito ramificados desde a base.

Nome comum: pitanga-preta, murta-preta.

Material examinado: BRASIL. Rio de Janeiro: Mangaratiba, Restinga da Marambaia, Praia da Armação, 24/X/1999, fr., Menezes 507 (RBR); 19/I/2002, fr., Menezes 927 (RBR); 15/XI/2002, fl., Menezes 1083 (RBR). Rio de Janeiro, Restinga da Marambaia, floresta de duna, 20/X/2000, fl., Souza 140 (RBR); 27/IX/2003, fl., Souza 268 (RBR); 25/X/2003, fr., Souza 283 (RBR).

\subsection{Eugenia uniflora L., Sp. pl. 1: 470-471. 1753.}

Lectótipo: Micheli, Nov. Pl. Gen. 226, t. 108. 1729 (F), designado por McVaugh (1956).

Figura 52-56

Arbusto a arvoreta de até 5 metros de altura, glabro; tronco com casca externa áspera e desprendendo-se em placas. Folhas ovadas ou elípticas, ápice agudo ou acuminado, base aguda, obtusa, arredondada, ou cordada, cartáceas a coriáceas, discolores, com pontuações não visíveis a olho nu em ambas as faces; $25-70 \times 15-35 \mathrm{~mm}$; nervura principal de sulcada a plana na face adaxial, saliente na abaxial; nervuras secundárias 6-8 pares pouco evidentes na face adaxial, visíveis e salientes na abaxial; nervura marginal não definida, com os laços de fechamento das nervuras secundárias em ângulo reto ou próximo à reto; pecíolo 1-4 mm compr. Flores em racemo "stenocalyx" axilares terminais, em nós folhosos basais ou áfilos, raque ca. $1 \mathrm{~mm}$ compr., 1-2 pares de flores; ferofilos ovados ou elípticos, 2-5 mm compr., ciliados; antopódio 15-30 mm compr.; profilos lanceolados ou lineares, ca. $1 \mathrm{~mm}$ compr., não conados, ciliados, decíduos. Botões florais globosos ou piriformes, hipanto com ovário 8-costado longitudinalmente, diferenciado do cálice; cálice ocultando parcialmente o globo petalífero; lobos do cálice oblongos, 3-4×1,5-2 mm, iguais, ciliados, após a antese reflexos escondendo o ovário. Fruto bacáceo globoso, costado longitudinalmente, 15-30 mm diâm., vermelho e com lobos do cálice verdes quando maduro.

Distribuição geográfica: no Brasil ocorre da Bahia ao Rio Grande do Sul, alcançando países vizinhos como Uruguai, Paraguai e Argentina (Legrand \& Klein 1969). Pode ser encontrada em outras regiões do Brasil, por ser muito cultivada. A espécie é muito abundante nas regiões litorâneas, associada aos locais arenosos e 


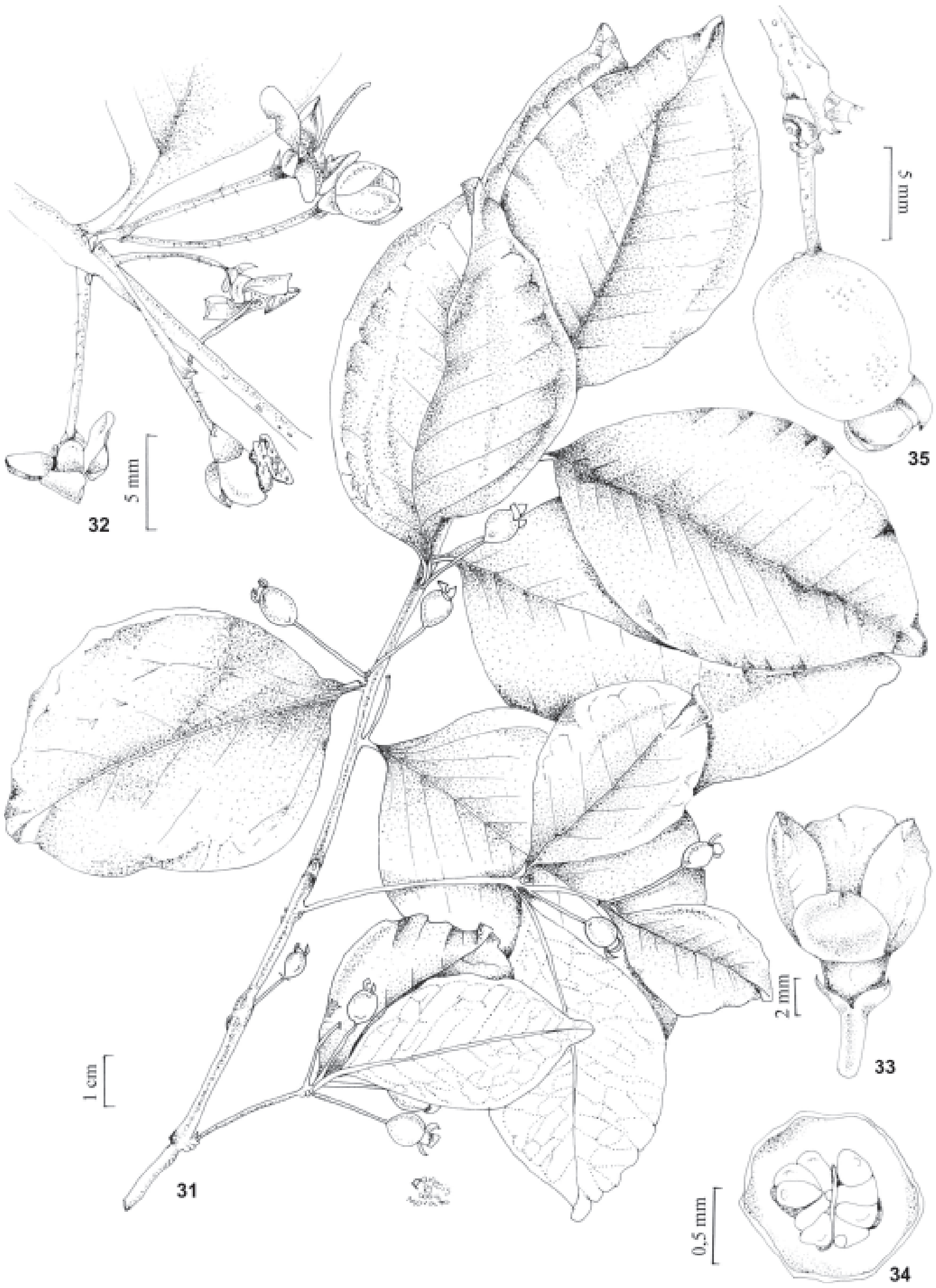

Figuras 31-35. Eugenia punicifolia (Kunth) DC.: 31. Ramo (Menezes 650). 32. Inflorescência em fascículo. 33. Botão floral. 34. Corte transversal do ovário (Pereira 4108). 35. Fruto (Menezes 650). 


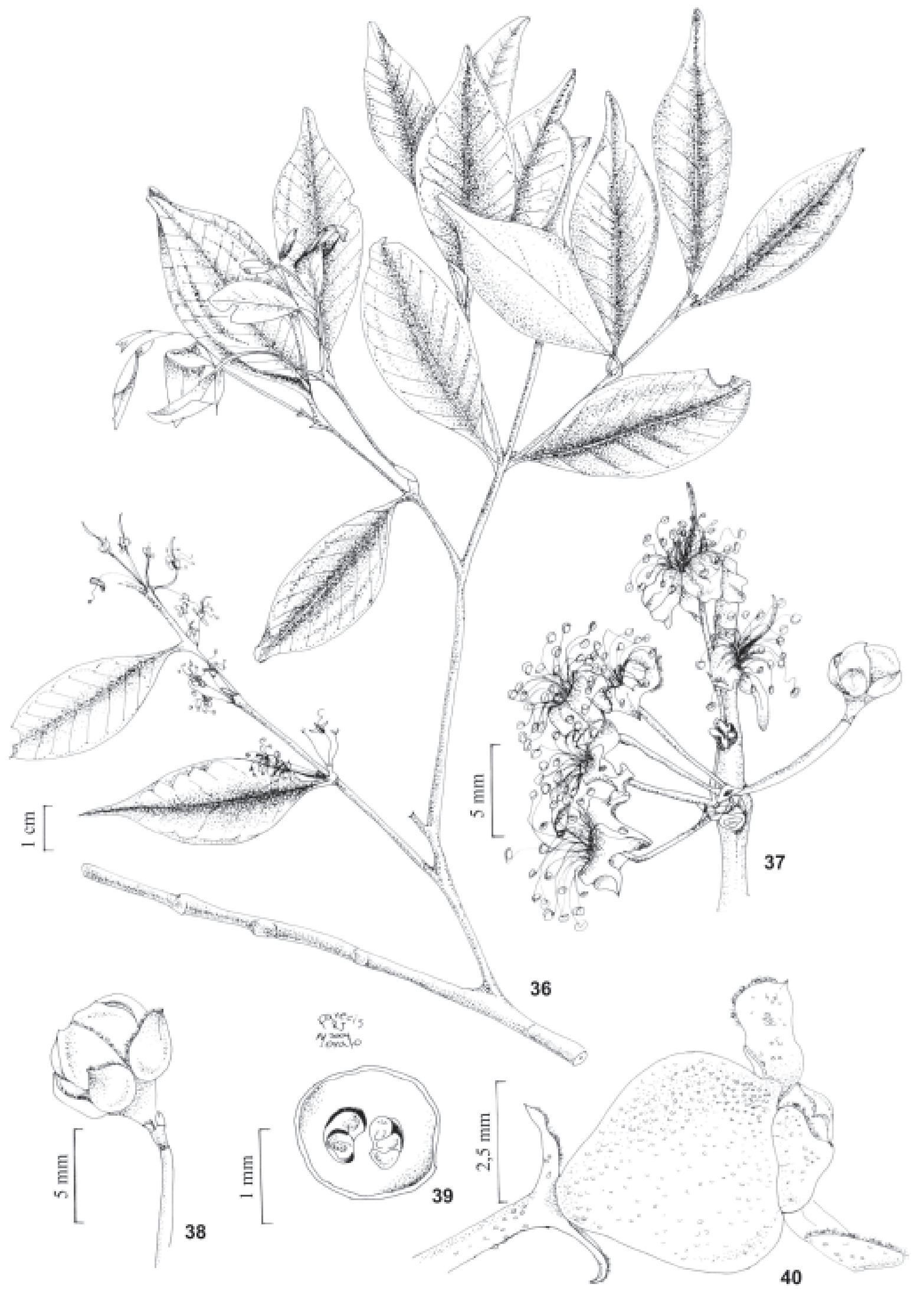

Figuras 36-40. Eugenia rostrata O. Berg: 36. Ramo. 37. Inflorescência em fascículo. 38. Botão floral. 39. Corte transversal do ovário (Menezes 510). 40. Fruto (Farney 3556). 


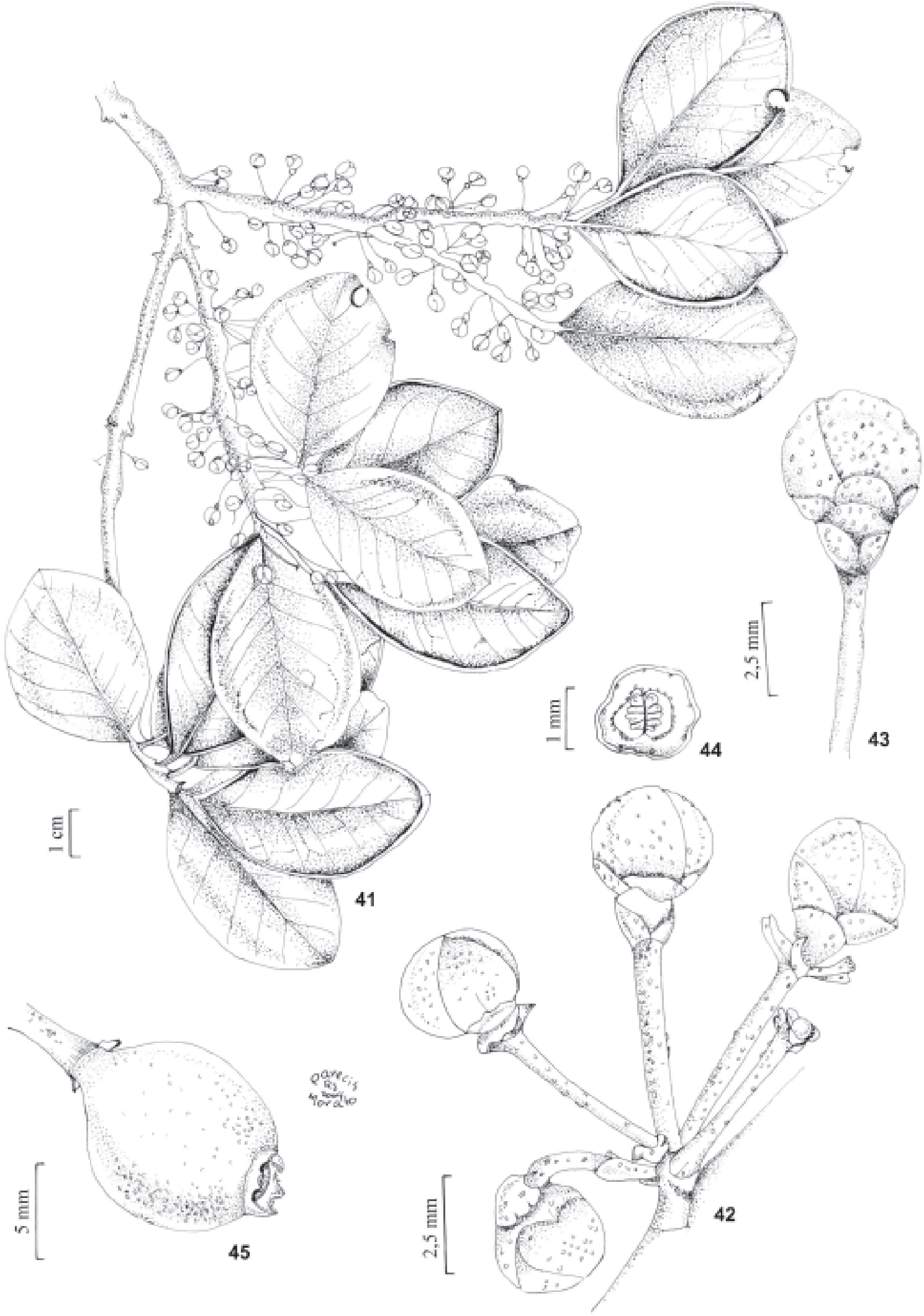

Figuras 41-45. Eugenia rotundifolia Casar.: 41. Ramo. 42. Inflorescência em fascículo. 43. Botão floral. 44. Corte transversal do ovário (Menezes 593). 45. Fruto (Araujo 752). 


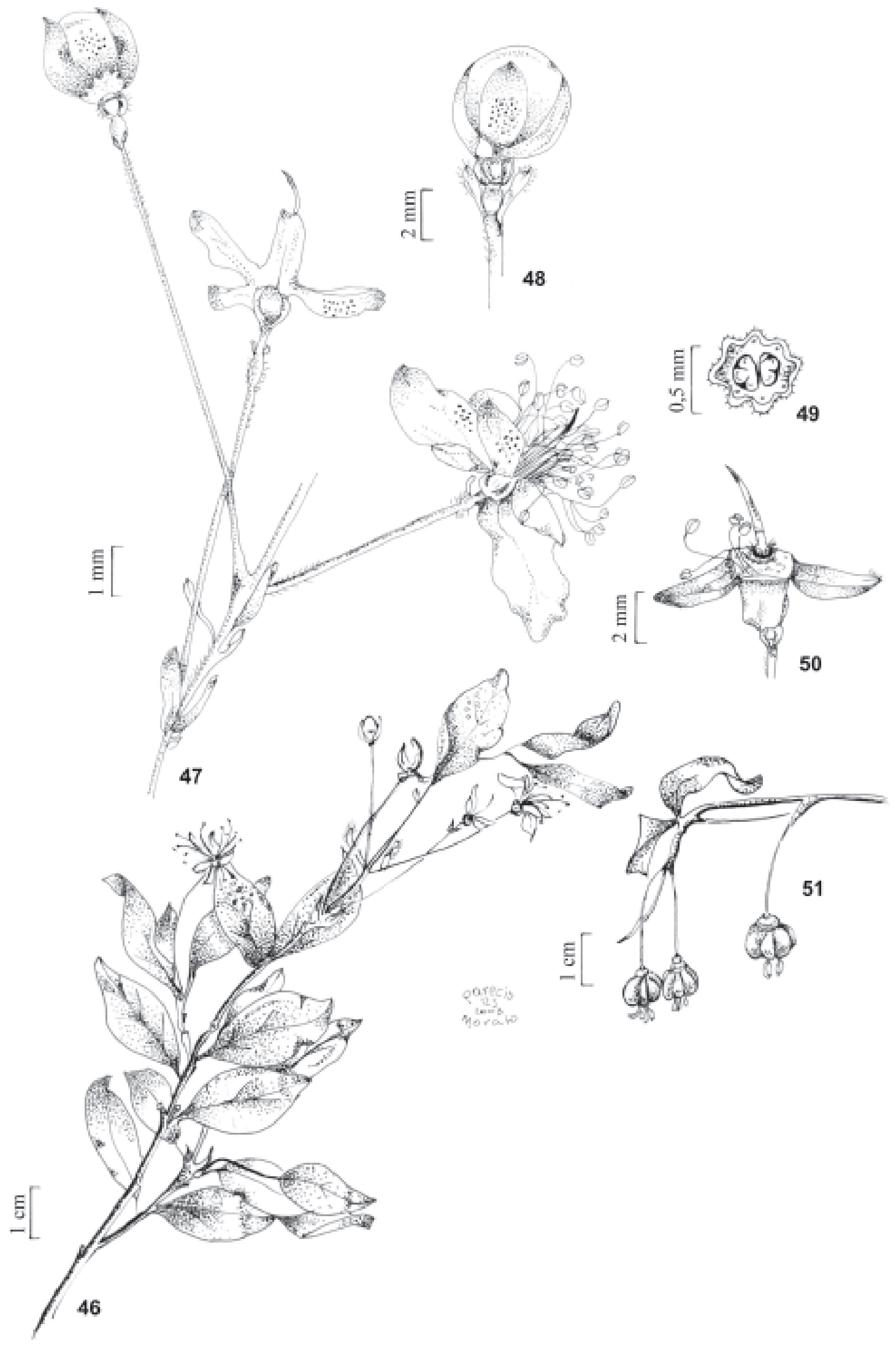

Figuras 46-51. Eugenia sulcata Spring ex Mart.: 46. Ramo. 47. Inflorescência em racemo“stenocalyx". 48. Botão floral. 49. Corte transversal do ovário. 50. Flor após antese (Souza 268). 51. Frutos (Souza 283). 


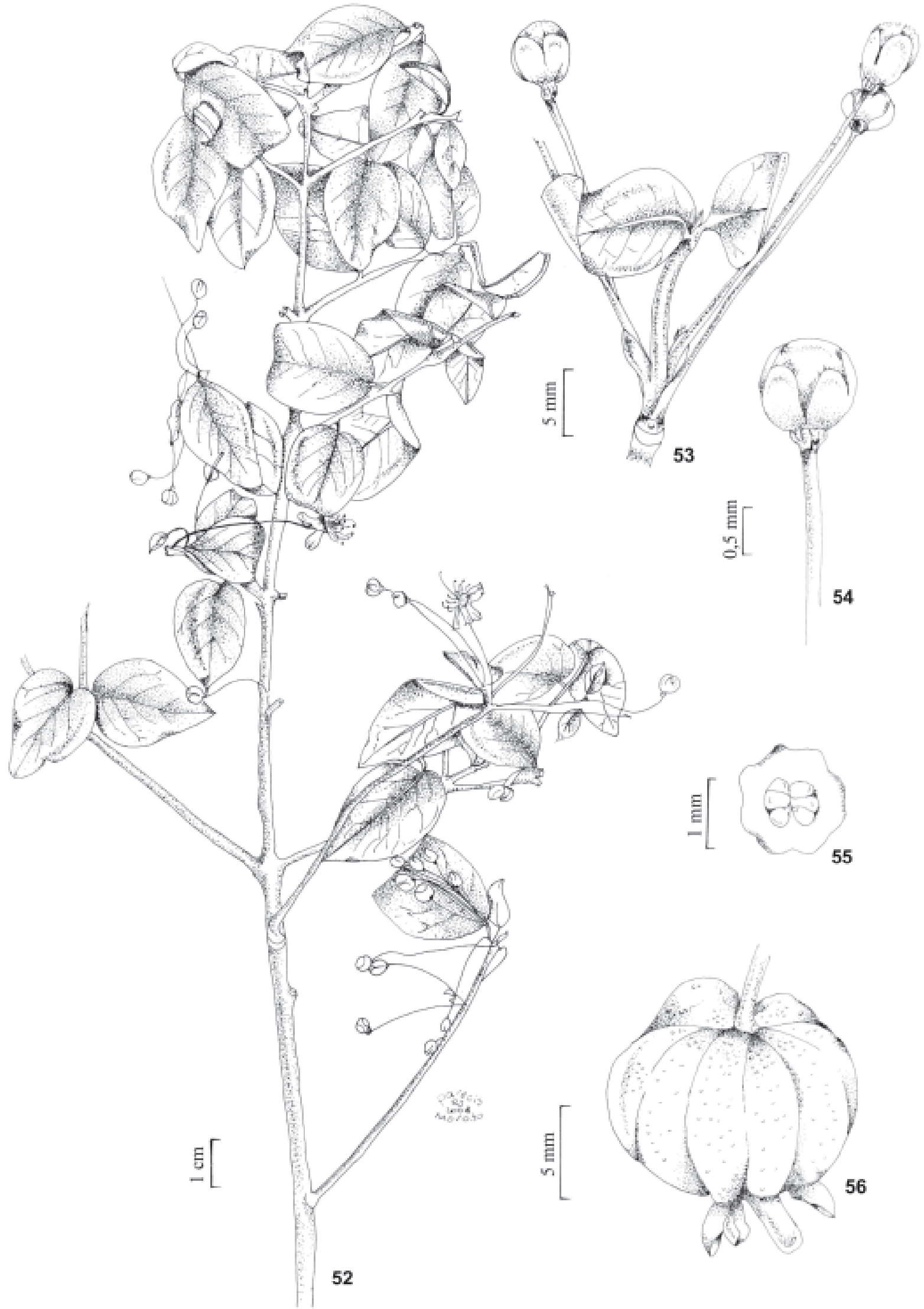

Figuras 52-56. Eugenia uniflora L.: 52. Ramo. 53. Inflorescência em racemo“stenocalyx". 54. Botão floral. 55. Corte transversal do ovário. 56. Fruto (Souza 300). 
ensolarados das restingas, porém habita ocasionalmente a Floresta Pluvial Atlântica. No Rio de Janeiro, distribui-se pelas seguintes áreas de restinga: Marambaia, Grumari, Jacarepaguá, Maricá, Cabo Frio e São João da Barra. Na Restinga da Marambaia foi encontrada na formação herbácea fechada de cordão arenoso, arbustiva fechada de cordão arenoso e na floresta de cordão arenoso.

Floração: quase todo o ano, com predomínio de agosto a outubro. Frutificação: quase todo o ano com predomínio de outubro a janeiro.

Comentário: a espécie é muito apreciada na alimentação e normalmente ocorre em populações concentradas próximo de áreas habitadas pelo homem.

Nome comum: pitanga.

Material examinado: BRASIL. Rio de Janeiro: Mangaratiba, Restinga da Marambaia, Praia da Armação, 2/VIII/2000, fl., Menezes 337 (RBR); 13/III/2003, fl., Menezes s.n. (RBR); 15/I/2004, fl., fr., Souza 300 (RBR). Rio de Janeiro, Restinga da Marambaia, floresta de duna, 2/VII/1999, fl., Souza 124 (RBR).

\subsection{Eugenia sp.}

Fig. 61-65

Arvoreta de até 7 metros de altura, glabra ou glabrescente, salvo alguns tricomas esparsos nos ramos novos; tronco com casca externa áspera. Folhas elípticas, ápice longamente acuminado, base cuneada, bordo ondulado e com espessamento amarelado, cartáceas, discolores, pontuações translúcidas densas e evidentes a olho nu em ambas as faces, superfície ondulada; 40-80×20-40 mm; nervura principal sulcada ou plana na face adaxial e saliente na abaxial; nervuras secundárias 8-10 pares visíveis em ambas as faces; nervura marginal 1-2 mm do bordo; pecíolo 5-7 mm compr., amarelado no material vivo e escurecido após herborizado. Fascículos axilares, terminais ou em nós folhosos basais, com 2 flores, com raque 2-3 mm compr.; ferofilos triangulares, ca. $1 \mathrm{~mm}$ compr., ciliados; antopódio 1-2 mm compr.; profilos arredondados, conados, ca. $1 \mathrm{~mm}$ compr., ciliados, persistentes na antese, abraçando e ocultando o ovário. Botões florais globosos, 3-4 mm diâm.; cálice ocultando o globo petalífero; lobos do cálice arredondados ou suborbiculares, até $2 \times 2 \mathrm{~mm}$, desiguais, com 2 maiores externos e 2 menores internos, ciliados. Fruto bacáceo globoso, até 15 mm diâm., vermelho quando maduro.

Distribuição geográfica: até o momento só foi registrada a ocorrência para a Restinga da Marambaia, sendo encontrada na formação arbustiva aberta não inundável e floresta de cordão arenoso.

Floração: novembro e janeiro. Frutificação: dezembro.

Comentário: planta muito característica pela presença de pontuações translúcidas grandes, muito evidentes a olho nu em ambas as faces e densamente distribuídas. Tem certa afinidade com Eugenia glandulosissima Kiaersk., da qual se distingue pela inflorescência menos desenvolvida e desprovida de indumento. Estudos complementares estão em andamento para definição de um melhor posicionamento taxonômico da espécie.

Material examinado: BRASIL. Rio de Janeiro: Mangaratiba, Restinga da Marambaia, Praia da Armação, 4/I/1999, fl., Menezes s.n. (RBR); 15/XI/2002, fl., Menezes 1070 (RBR); estrada que vai para a Praia da Gaeta, 27/XII/2002, fr., Souza 255 (RB).

\section{Myrciaria O. Berg, Linnaea 27: 320. 1856.}

Lectótipo: Myrciaria tenella (DC.) O. Berg, designado por McVaugh (1956).

$\mathrm{O}$ gênero se distingue pelas inflorescências em fascículos, axilares, em nós folhosos basais ou áfilos; profilos conados, persistentes após a antese. Flores tetrâmeras; cálice ocultando o globo petalífero no botão floral, com lobos decíduos após a antese por cisão transversal no hipanto; hipanto sem ovário e cálice diferenciados, prolongado acima do ovário; pétalas presentes; ovário bilocular, com 2 óvulos por lóculo. Fruto bacídio com pequena cicatriz circular deixada pela cisão no hipanto; 1-2 sementes; embrião eugenióide.

Gênero com espécies distribuídas desde o México e Caribe até o norte da Argentina. No Brasil ocorrem cerca de 30 espécies, principalmente na região sudeste (Landrum \& Kawasaki 1997). Foram encontradas duas espécies na Restinga da Marambaia: Myrciaria floribunda e M. tenella.

\subsection{Myrciaria floribunda (H. West ex Willd.) O.} Berg, Linnaea 27(2, 3): 330. 1856.

Basiônimo: Eugenia floribunda $\mathrm{H}$. West ex Willd., Sp. pl. 2: 960. 1799.

Tipo: Habitat in insula St. Crucis, West s.n., s.d. (B)

Fig. 66-71

Arbusto a arvoreta de até 5 metros de altura; ramos, face abaxial das folhas, cálice e profilos glabros ou com tricomas esparsos; tronco com casca externa laminada desfoliante em placas rígidas, deixando um 


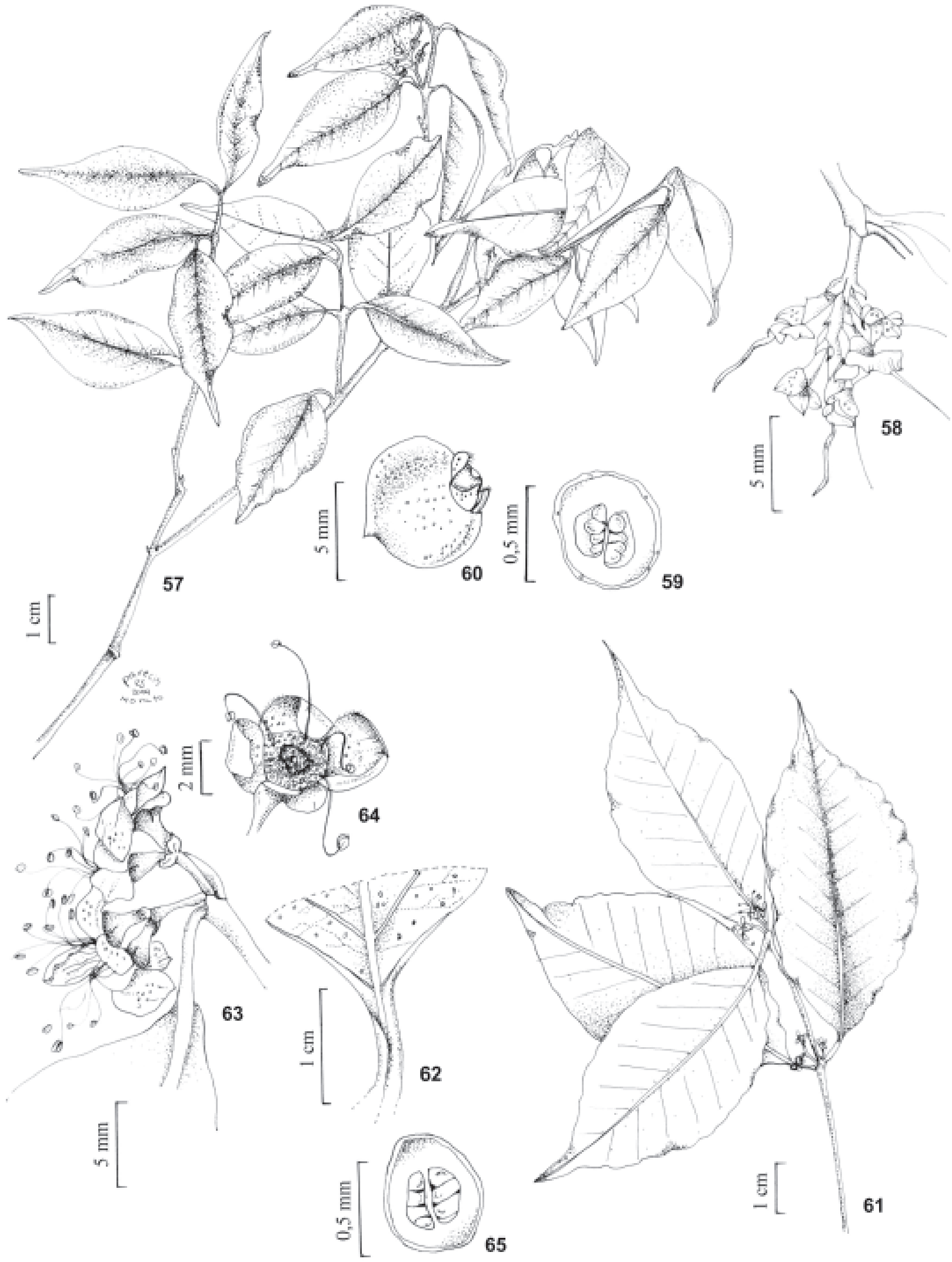

Figuras 57-60. Eugenia oxyoenthophylla Kiaersk.: 57. Ramo. 58. Inflorescência em fascículo. 59. Corte transversal do ovário. 60. Fruto (Menezes 521). Figuras 61-65. Eugenia sp.: 61. Ramo. 62. Detalhe da folha. 63. Inflorescência em fascículo. 64. Flor. 65. Corte transversal do ovário (Menezes 1070). 
aspecto liso, amarelado ou rosado. Folhas elípticas ou lanceoladas, ápice longo-acuminado, base cuneada ou decurrente, bordo não revoluto, cartáceas, discolores, densamente pontuadas; $25-60 \times 10-30 \mathrm{~mm}$; nervura principal sulcada ou plana na face adaxial e saliente na abaxial; nervuras secundárias 15-20 pares, visíveis em ambas as faces; nervura marginal 0,5-1 $\mathrm{mm}$ do bordo; pecíolos 5-8 mm compr., amarelados e enegrecidos após herborizados. Inflorescências em nós folhosos basais ou áfilos, com até 6 flores, eixo ca. $1 \mathrm{~mm}$; ferofilos suborbiculares, ca. $0,5 \mathrm{~mm}$ compr., ciliados; antopódio ca. $0,5 \mathrm{~mm}$ compr.; profilos arredondados ou suborbiculares, ca. $1 \mathrm{~mm}$ compr., cilados. Botões florais globosos, ca. 2 mm diâm.; cálice não ocultando o globo petalífero, lobos caliciniais ciliados. Fruto globoso, até 13 mm diâm., alaranjado a vermelho quando maduro.

Distribuição geográfica: América Central e América do Sul (Sobral 1993). No Rio de Janeiro, distribui-se pelas seguintes áreas de restinga: Marambaia, Jacarepaguá, Maricá, Cabo Frio e Macaé. $\mathrm{Na}$ Restinga da Marambaia foi encontrada na formação arbustiva aberta não inundável, na arbustiva fechada de cordão arenoso, na arbustiva fechada de pós-praia e na floresta de cordão arenoso.

Floração: de dezembro a janeiro. Frutificação: de julho a outubro.

Comentário: a espécie apresenta uma grande variação morfológica nas folhas e uma ampla distribuição geográfica, o que acarretou numa grande lista de sinônimos, conforme já mencionado por Sobral (1993). Os espécimes coletados nas restingas do Rio de Janeiro apresentam caracteres que facilitam a identificação, como as folhas com pecíolos longos e de coloração amarelada na natureza, além do freqüente desenvolvimento de galhas sobre a lâmina foliar, as quais se assemelham a uma roseta de folhas e medem ca. $10 \mathrm{~mm}$ compr.

Nome comum: camboim.

Material examinado: BRASIL. Rio de Janeiro: Mangaratiba, Restinga da Marambaia, Praia da Armação, complexo florestal inundável, 11/XI/2000, vg., Menezes 704 (RBR); área de moitas, 31/X/2003, fr., Souza 292 (RBR). Rio de Janeiro, Restinga da Marambaia, floresta de duna, 9/I/1999, fl., Menezes 621 (RBR); 5/II/1999, fl., Menezes s.n. (RBR); 21/III/1999, fl., Menezes 240 (RBR); 29/XII/2000, fl., Souza 158 (RBR).

2.2. Myrciaria tenella (DC.) O. Berg, Linnaea 27: 328.1856.
Basiônimo: Eugenia tenella DC., Prodr. 3: 272. 1828. Tipo: Brasiliae montibus excelsis prov. Minarum, Martius s.n., s.d. (foto do tipo M!)

Fig. $72-76$

Arvoreta de até 5 metros de altura, com ramos novos, face abaxial das folhas, principalmente sobre a nervura principal, pecíolos, inflorescências e flores com pubescência de hialina a castanha; tronco com casca externa laminada desfoliante em placas rígidas, deixando um aspecto liso e vermelho. Folhas elípticas ou oblongas, ápice agudo, às vezes curtamente obtusoacuminado, base aguda ou cuneada, bordo espessado e revoluto, cartáceas, discolores, com pontuações verrucosas evidentes, principalmente, na face abaxial; 15-25 $\times 5-8 \mathrm{~mm}$; nervura principal plana ou sulcada na face adaxial e saliente na abaxial; nervuras secundárias 10-12 pares, tenuemente impressas em ambas as faces; nervura marginal 0,1-0,5 mm do bordo; pecíolos ca. $1 \mathrm{~mm}$ compr. Inflorescências em nós folhosos basais, com até 4 flores, com eixo inconspícuo e coberto pelos ferofilos; ferofilos ovados, ca. 0,5 mm compr., ciliados; antopódio ca. $1 \mathrm{~mm}$ compr.; profilos ovado-arredondados, ca. $0,5 \mathrm{~mm}$ compr., ciliados. Botões florais globosos, 1-1,5 mm diâm.; cálice ocultando o globo petalífero, lobos caliciniais ciliados. Fruto globoso, até $8 \mathrm{~mm}$ diâm., alaranjado quando maduro.

Distribuição geográfica: América Central, Venezuela, Argentina, Uruguai e Brasil, onde ocorre do Pará ao Rio Grande do Sul (Sobral 1993). No Rio de Janeiro distribui-se pelas seguintes áreas de restinga: Marambaia, Jacarepaguá e Cabo Frio. Na Restinga da Marambaia foi encontrada na formação arbustiva fechada de cordão arenoso e floresta de cordão arenoso.

Floração: dezembro. Frutificação: janeiro.

Comentário: a espécie é facilmente reconhecida nas áreas de restinga do Rio de Janeiro por apresentar folhas miúdas, além de um tronco com casca laminada, desfolhando em placas, deixando um aspecto liso e vermelho; comumente os indivíduos são encontrados muito ramificados desde a base.

Nome comum: camboim, murta.

Material examinado: BRASIL. Rio de Janeiro: Mangaratiba, Restinga da Marambaia, Praia da Armação, 27/I/2001, vg., Menezes 211 (RBR). Rio de Janeiro, Restinga da Marambaia, floresta de duna, 27/I/2001, fr., Souza 186 (RBR); 27/I/2001, fr., Silva s.n. (RBR); Barra da Tijuca, 16/XII/1971, fl., Sucre $8116(\mathrm{RB})$. 


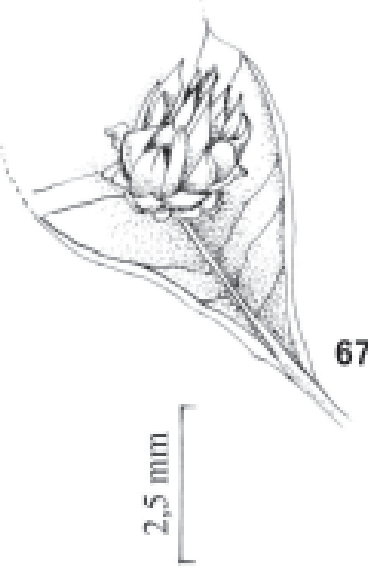

67
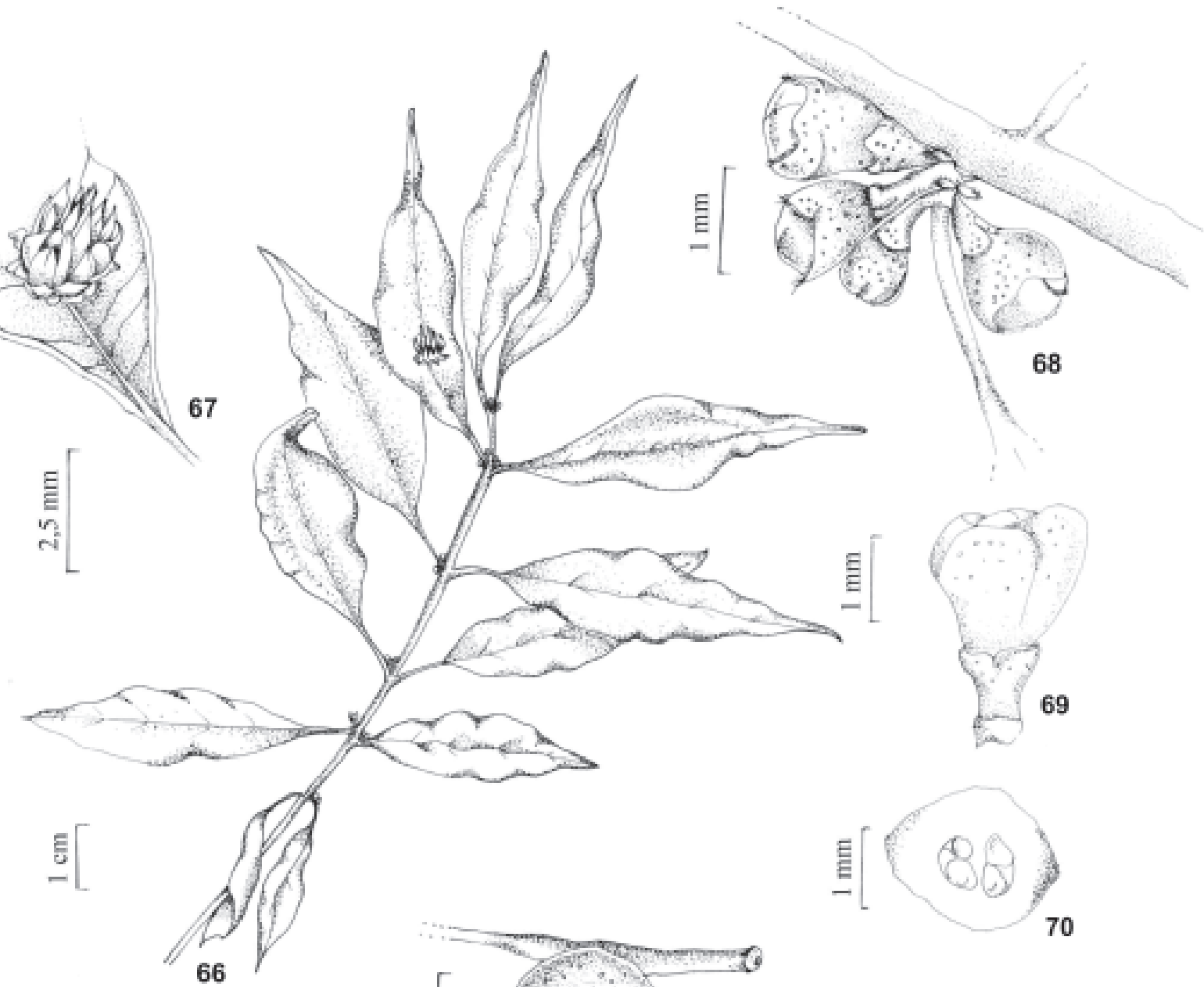

66
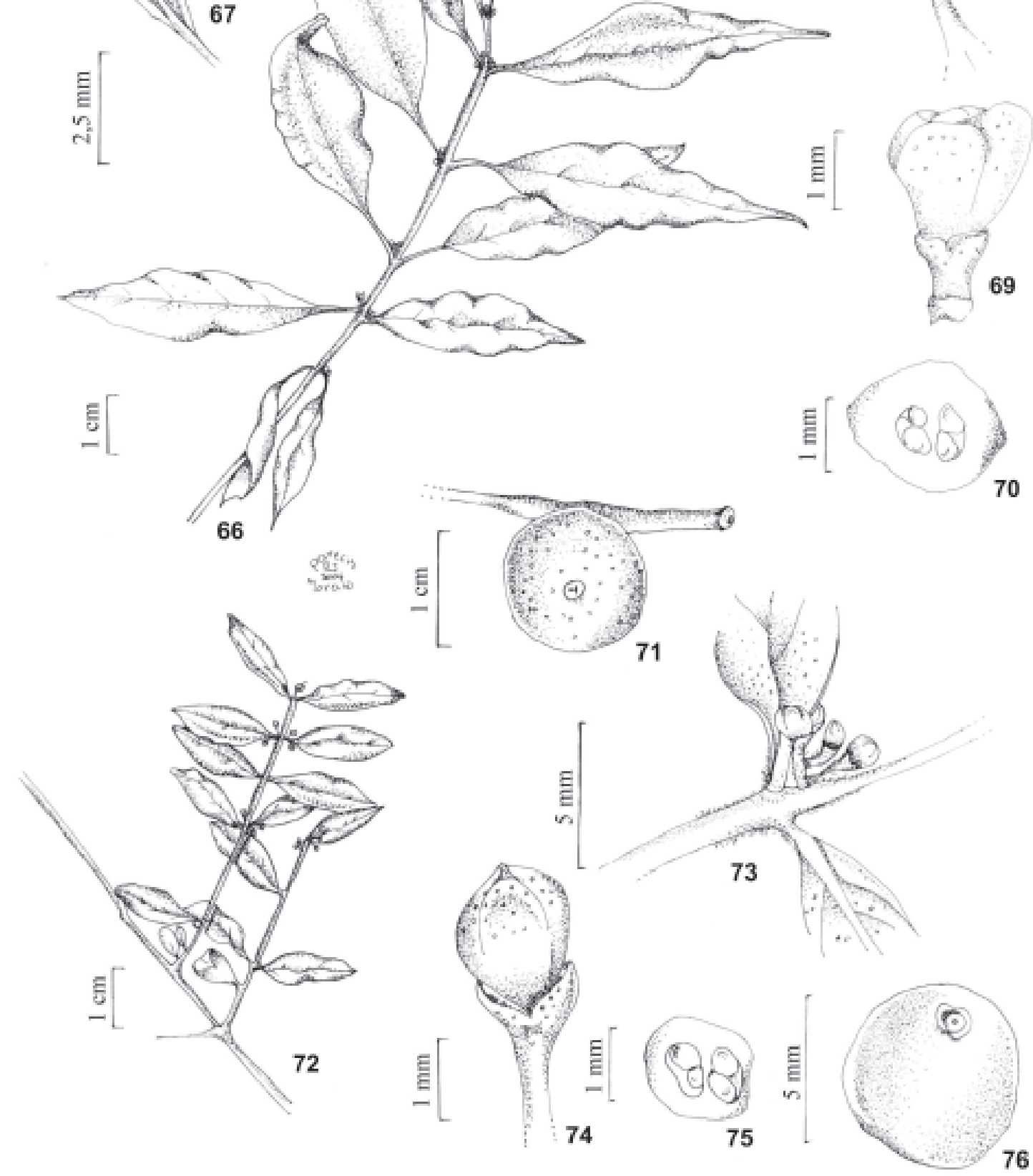

Figuras 66-71. Myrciaria floribunda (H. West ex Willd.) O. Berg: 66. Ramo. 67. Galha foliar (Souza 158). 68. Inflorescência em fascículo. 69. Botão floral. 70. Corte transversal do ovário (Menezes 240). 71. Fruto (Souza 292). Figuras 72-76. Myrciaria tenella (DC.) O. Berg: 72. Ramo. 73. Inflorescência em fascículo. 74. Botão floral. 75. Corte transversal do ovário (Sucre 8116). 76. Fruto (Souza 186). 
3. Neomitranthes Kausel ex D. Legrand, Fl. Il. Catarin. 15: 671. 1977.

Tipo: Neomitranthes glomerata (D. Legrand) D. Legrand (Legrand \& Klein 1977).

O gênero, estabelecido por Legrand em Legrand \& Klein (1977), foi baseado no subgênero de mesmo nome, descrito por Kausel para o gênero Mitranthes O. Berg, porém não publicado. Este último foi transferido para a subtribo Myrciinae, após o reconhecimento do embrião mircióide para a espécietipo, Mitranthes ottonis O. Berg (McVaugh 1968). Ao antigo subgênero Neomitranthes ficaram subordinadas as espécies com embriões típicos eugenióides.

Neomitranthes é um gênero exclusivamente brasileiro e que provavelmente não ultrapasse 10 espécies (Sobral 2003). Na Restinga da Marambaia está representado apenas por Neomitranthes obscura.

3.1. Neomitranthes obscura (DC.) N. Silveira, Roessleria 4(1): 123. 1981.

Basiônimo: Calyptranthes obscura DC., Prodr. 3: 257. 1828.

Tipo: Brasil, Martius s.n., s.d. (foto do holótipo M!, foto dos isótipos $\mathrm{P}$ !, $\mathrm{K}$ !).

Fig. 77-84

Arbusto a arvoreta de até 5 metros de altura, glabros ou com alguns poucos tricomas nos ramos novos, face abaxial das folhas e pecíolos; tronco com casca externa áspera e desprendendo-se em placas. Folhas ovadas ou elípticas, ápice acuminado, base cuneada a decurrente, bordo foliar espessado, amarelado, às vezes revoluto, coriáceas, discolores, densamente translúcido-pontuadas; 30-60×13-30 mm; nervura principal saliente em ambas as faces; nervuras secundárias ca. 10 pares, tênues em ambas as faces; nervura marginal ca. $1 \mathrm{~mm}$ do bordo; pecíolos 3-5 mm compr., podendo ser amarelado na natureza. Fascículos axilares, em nós folhosos basais ou áfilos, com 4-6 flores, raque com ca. $1 \mathrm{~mm}$; ferofilos triangulares, ca, $1 \mathrm{~mm}$ compr., ciliados; antopódio ca. $0,5 \mathrm{~mm}$ compr.; profilos triangulares, conados, ca. $0,5 \mathrm{~mm}$ compr., ciliados, persistentes na antese. Botões florais obovados, apiculados, 2-6×4 mm; hipanto sem ovário e cálice diferenciados, prolongado acima do ovário, campanulado; cálice fechado no botão, lobos caliciniais indistintos, abrindo-se por uma caliptra; pétalas reduzidas, espatuladas, ciliadas, caducas, 4; ovário bilocular, com 2 óvulos por lóculo. Fruto bacídio, globoso, até 15 mm diâm., coroado pelo hipanto e com cicatriz da caliptra, enegrecido quando maduro; $1-2$ sementes; embrião eugenióide.

Distribuição geográfica: nas restingas do Espírito Santo e Rio de Janeiro. Neste Estado ocorre nas seguintes áreas: Restinga da Marambaia, Jacarepaguá, Maricá, Cabo Frio, Macaé e São João da Barra. Na Restinga da Marambaia foi encontrada na formação arbustiva aberta não inundável, na arbustiva fechada de cordão arenoso e na floresta de cordão arenoso.

Floração: de maio a setembro. Frutificação: de agosto a dezembro.

Comentário: a espécie é muito característica por apresentar folhas densamente translúcido-pontuadas e face adaxial muito brilhosa na natureza. Os espécimes são comumente encontrados com galhas, que se desenvolvem nos ramos jovens e com aspecto de uma roseta, de tamanho em torno de 30-40 mm compr.

Nome comum: camboim-de-cachorro, pitanga-decachorro.

Material examinado: BRASIL. Rio de Janeiro: Mangaratiba, Restinga da Marambaia, Praia da Armação, 29/V/1999, fl., Menezes 294 (RBR); 24/X/1999, fr., Menezes 516 (RBR); 17/V/2000, fl., Menezes 609 (RBR); 12/VI/2000, fl., Menezes 571 (RBR); 31/X/2003, fr., Souza 293 (RBR). Rio de Janeiro, Restinga da Marambaia, floresta de duna, 2/VII/1999, fl., Souza 131 (RBR); 9/IX/1999, fr., Souza 132 (RBR); 29/XII/2000, fl., Souza 159 (RBR).

4. Plinia L., Sp. pl. : 516. 1753.

Tipo: Plinia pinnata L.

O gênero tem como área de distribuição a América Central, Caribe e Brasil e abrange cerca de 20 espécies (Landrum \& Kawasaki 1997). Na Restinga da Marambaia ocorre apenas Plinia ilhensis.

4.1. Plinia ilhensis G.M. Barroso, Napaea 10: 2, fig. 1. 1994.

Tipo: Brasil, Rio de Janeiro, Baía de Sepetiba, Ilha Furtada, Sucre 2010, 24-XII-1967 (holótipo RB!). Fig. 85-87

Arbusto de até 2,5 metros de altura, com ramos novos, face abaxial e pecíolos das folhas novas, inflorescências, flores e frutos pubescentes; tronco com casca externa áspera. Folhas elípticas, suborbiculares, oblongas ou raramente ovadas, ápice obtusoacuminado, obtuso ou arredondado, base cuneada ou arredondada, bordo foliar amarelado, revoluto, cartáceas a coriáceas, discolores, pontuações 


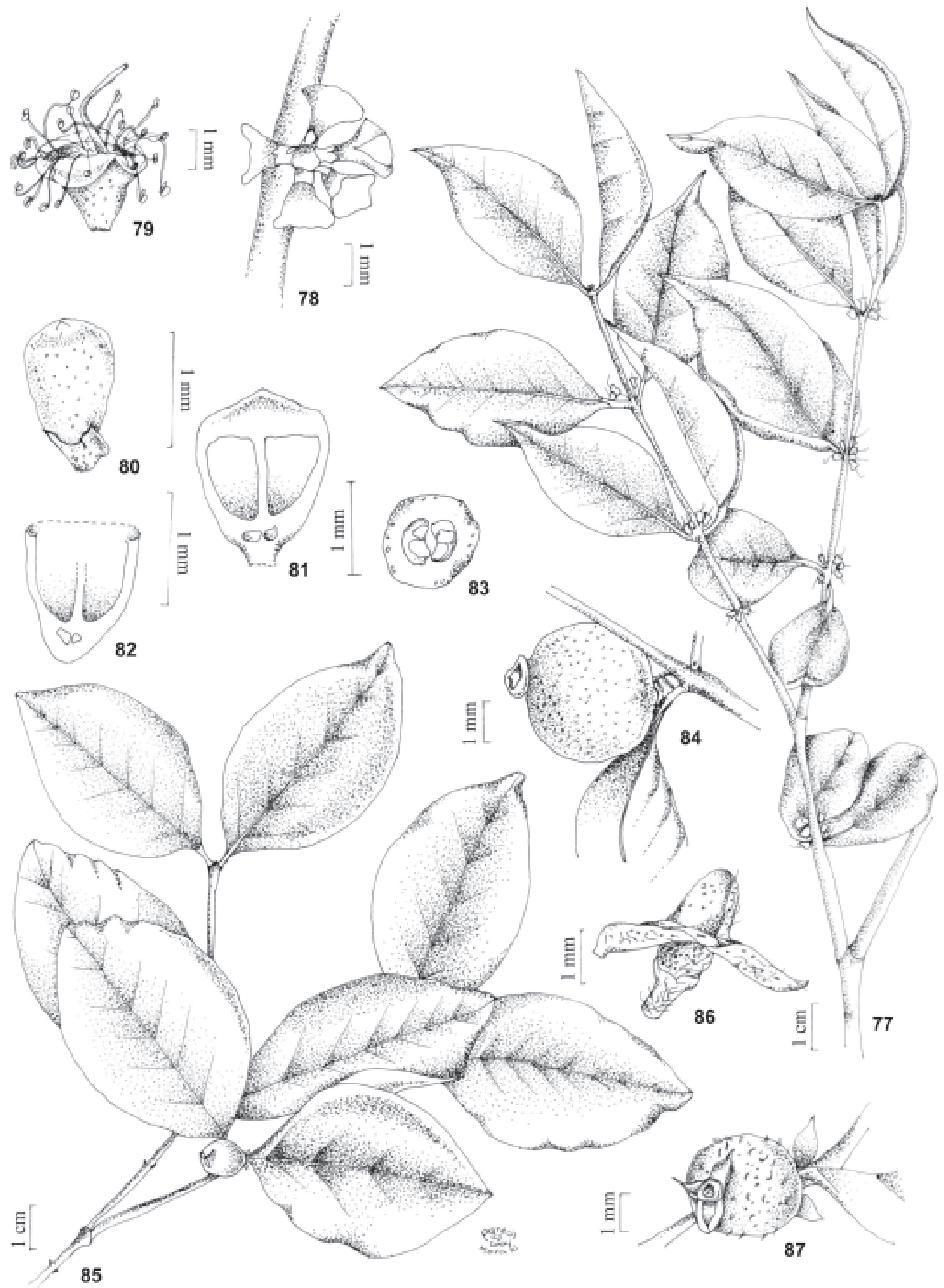

Figuras 77-84. Neomitranthes obscura (DC.) N. Silveira: 77. Ramo. 78. Inflorescência em fascículo. 79 . Flor aberta. 80 botão floral. 81. Corte longitudinal do botão floral. 82. Corte longitudinal da flor aberta. 83. Corte transversal do ovário (Menezes 294). 84. Fruto (Souza 293). Figuras 85-87. Plinia ilhensis G.M. Barroso: 85. Ramo. 86. Flor aberta. 87. Fruto (Souza 308). 
translúcidas diminutas e pouco visíveis; 20-90x $15-45 \mathrm{~mm}$; nervura principal sulcada na face adaxial e saliente na abaxial; nervuras secundárias 5-10 pares evidentes em ambas as faces; nervura marginal 1,5-4 $\mathrm{mm}$ do bordo; pecíolos 2-5 $\mathrm{mm}$ compr. Inflorescências em fascículos axilares, em nós folhosos basais ou áfilos, com raque muito curta; ferofilos muito reduzidos, ca. 0,1 mm compr.; antopódio ca. $1 \mathrm{~mm}$ compr.; profilos triangulares, conados, ca. $1,5 \mathrm{~mm}$ compr., ciliados, persistentes na antese. Botões florais obovados, 3-4×4 mm, hipanto sem ovário e cálice diferenciados, prolongado acima do ovário; cálice fechado no botão, lobos caliciniais indistintos, rompendo-se em 3-4 lobos triangulares, irregulares e fendidos até o ápice do ovário; pétalas presentes, cedo caducas; ovário bilocular, com 2 óvulos por lóculo. Fruto bacóide globoso, 8-14 mm diâm., com os lobos do cálice persistentes; 1-2 sementes; embrião eugenióide.

Distribuição geográfica: até o momento só foi registrada a ocorrência para o Rio de Janeiro, em Floresta Pluvial Atlântica e em restinga, sendo registrada apenas para a Restinga da Marambaia, em floresta inundável.

Floração: de dezembro a março. Frutificação: de janeiro a abril.

Comentário: a espécie só era conhecida pelo material-tipo. Com este estudo foi possível a coleta de outros exemplares, bem como registros de novas áreas de ocorrência no Rio de Janeiro. Na Restinga da Marambaia a espécie é muito rara, sendo encontrada uma pequena população restrita a um trecho de floresta inundável.

Material examinado: BRASIL. Rio de Janeiro: Búzios, Serra das Emerências, 22/IV/1999, fr., Lobão 413 (RB); 22/IV/1999, fr., Lobão 414 (RB). Mangaratiba, Restinga da Marambaia, estrada que vai para a Gaeta, 15/I/2004, fr., Souza 306 (RBR). Rio de Janeiro, Reserva Ecológica da Prainha, Morro da Boa Vista, 19/III/2004, fl., fr., Souza 308 (RB).

\section{Subtribo Myrtinae}

Inflorescências em mônades ou dicásios, axilares em nós folhosos ou áfilos, ou em outras regiões dos ramos; flores tetrâmeras ou pentâmeras; botão aberto, parcialmente aberto ou fechado, abrindo-se pelo rasgamento do hipanto em 4-5 lobos irregulares; pétalas presentes; androceu com 5-8 estames ou polistêmone; hipanto prolongado ou não acima do ovário; estigma punctiforme ou globoso; ovário 2, 3 ou 5-locular, 4 ou pluriovulados por lóculo. Frutos bacáceo ou solanídio, 1-4 ou multiseminado; embrião mirtóide, com o eixo hipocótilo-radícula bem desenvolvido e cotilédones pequenos ou vestigiais.

\section{Blepharocalyx O. Berg, Linnaea 27: 412. 1856.}

Lectótipo: Blepharocalyx acuminatissimus (Miq.) O. Berg (= B. salicifolius), designado por McVaugh (1956).

Gênero com apenas três espécies de distribuição disjunta nos Andes, Antilhas e Brasil (Landrum 1986). $\mathrm{Na}$ Restinga da Marambaia ocorre Blepharocalyx salicifolius.

\subsection{Blepharocalyx salicifolius (Kunth) O. Berg,} Linnaea 27: 413. 1856.

Basiônimo: Myrtus salicifolia Kunth, Nov. Gen. Sp. 6: 136.1823.

Tipo: Equador, prope Loxam Novo-Granatensium, Humboldt et Bonpland s.n. (foto do tipo P!)

Fig. 88-91

Arvoreta a árvore de até 7 metros de altura; ramos e folhas novos com indumento alvo-seríceo; tronco com casca externa áspera, desprendendo-se em placas. Folhas elípticas, ápice acuminado e mucronado; base aguda ou cuneada, cartáceas, discolores, com pontuações evidentes na face abaxial; 20-45x 10-20 mm; nervura principal sulcada a plana na face adaxial, saliente na abaxial; nervuras secundárias 15-20 pares, evidentes e salientes em ambas as faces; nervura marginal ca. 0,5 $\mathrm{mm}$ do bordo; pecíolo 2-3 $\mathrm{mm}$ compr. Inflorescências em dicásios axilares em nós folhosos basais, 3-15 flores; hipopódio 15-30 mm compr.; antopódio presente nas flores laterais com 2-7 mm compr. e ausente nas flores centrais; ferofilos e profilos decíduos, não vistos. Flores tetrâmeras, botões florais com cálice aberto, piriformes, $3 \times 2 \mathrm{~mm}$, hipanto com ovário e cálice diferenciados; cálice ocultando o globo petalífero; lobos caliciniais iguais, distintos, ovadoelípticos, côncavos, densamente ciliados, decíduos após a antese; pétalas presentes; androceu com mais de 20 estames; estigma punctiforme; ovário bilocular, com 4 ou mais óvulos por lóculo; hipanto não desenvolvido. Fruto não visto.

Distribuição geográfica: Paraguai, Uruguai, norte da Argentina, Bolívia, Equador e no Brasil distribui-se de Goiás ao Rio Grande do Sul (Landrum 1986), ocorrendo em fitofisionomias diversas. Nas restingas do Rio de Janeiro encontra-se nas seguintes áreas: Marambaia e Jacarepaguá. Na Restinga da Marambaia foi encontrada somente na floresta de cordão arenoso. 
Floração: de setembro a janeiro. Frutificação: não observada.

Comentário: a espécie apresenta grande variação na morfologia foliar e em conseqüência há uma grande lista de sinônimos já mencionados por Landrum (1986). Os epécimes coletados nas restingas do Rio de Janeiro são característicos pela folha com ápice mucronado.

Nome comum: cambuí.

Material examinado: BRASIL. Rio de Janeiro: Mangaratiba, Restinga da Marambaia, Praia da Armação, complexo florestal inundável, 19/I/2001, fl., Souza 165 (RBR).

\section{Myrrhinium Schott, Syst. Veg. 4 (2): 405.1827.}

Tipo: Myrrhinium atropurpureum Schott

O gênero foi revisado por Landrum (1986), que reconheceu a existência de uma única espécie, Myrrhinium atropurpureum Schott, à qual está subordinada a variedade $M$. atropurpureum var. octandrum Benth. A variedade típica é restrita às restingas do Rio de Janeiro e M. atropurpureum var. octandrum ocorre no sudeste-sul do Brasil, Uruguai, Argentina e nos Andes.

6.1. Myrrhinium atropurpureum Schott var. atropurpureum, Syst. Veg. 4(2): 405. 1827.

Tipo: Brasil, Schott s.n., s.d., (holótipo BP).

Fig. 92-96

Arbusto a arvoreta de até 5 metros de altura; ramos jovens seríceos a pubérulos ou glabrescentes; tronco com casca externa áspera. Folhas elípticas, ápice obtuso ou arredondado, base aguda, obtusa ou arredondada, bordo revoluto, coriáceas, discolores, com a face adaxial nítida, densamente pontuadas; $25-50 \times$ 10-35 mm; nervura principal sulcada na face adaxial e saliente na abaxial; nervuras secundárias 6-9 pares, salientes ou não em ambas as faces; nervura marginal 1-3 mm do bordo; pecíolo 2-3 mm compr. Inflorescências em dicásios axilares, em nós áfilos, 3-15 flores, hipopódio 3-5 mm compr.; antopódio 2-4 mm compr., ausente nas flores centrais; ferofilos e profilos triangulares ca. $1 \mathrm{~mm}$ compr., ciliados, persistentes na antese. Flores tetrâmeras, botões florais com cálice aberto, piriformes, 5-6×2-3 mm; hipanto com ovário e cálice diferenciados; cálice não ocultando o globo petalífero; lobos caliciniais distintos, ovais ou orbiculares, ca. $1 \mathrm{~mm}$ compr., ciliados; pétalas elípticas a ovais, $4-5 \times 2-3 \mathrm{~mm}$, de vermelhas a roxas e suculentas, ciliadas; 5-8 estames, de 20-25 mm compr., vermelhos; estigma punctiforme; ovário bilocular, multiovulado por lóculo; hipanto prolongado acima do ovário. Fruto bacáceo, globoso-elíptico ou obovado, ca. 6 mm compr., negro quando maduro; 1-4 sementes reniformes, com testa lúcida; embrião mirtóide.

Distribuição geográfica: restrita às restingas do Rio de Janeiro, ocorrendo nas seguintes áreas: Marambaia, Grumari, Jacarepaguá, Maricá, Cabo Frio e Barra de São João. Na Restinga da Marambaia foi encontrada na formação herbácea fechada de cordão arenoso, arbustiva aberta não inundável, arbustiva fechada de cordão arenoso e arbustiva fechada de póspraia.

Floração: de julho a novembro. Frutificação: de outubro a março.

Comentário: a espécie é muita característica por apresentar flores com as pétalas vermelhas a roxas, suculentas e adocicadas, principalmente por ocasião da abertura das anteras, e poucos estames de coloração vermelha.

Nome comum: pau-ferro, carrapatinho.

Material examinado: BRASIL. Rio de Janeiro: Mangaratiba, Restinga da Marambaia, área da Aeronáutica, 3/I/2002, fr., Menezes 881 (RBR). Rio de Janeiro, Restinga da Marambaia, floresta de duna, 20/X/2000, fl., Souza 139 (RBR); 9/III/2002, fr., Souza 238 (RBR); 27/IX/2003, fl., Souza 270 (RBR).

7. Psidium L., Sp. pl. 1: 470. 1753.

Lectótipo: Psidium guajava L., designado por McVaugh (1968).

$\mathrm{O}$ gênero se distingue pelos botões florais que se rompem em 4-5 lobos irregulares; pétalas presentes; estigma globoso; ovário com numerosos óvulos por lóculos, aderidos a uma placenta desenvolvida que se projeta em direção ao centro do lóculo; hipanto prolongado sobre o ovário. Fruto solanídio, plurisseminado, sementes com testa óssea; embrião mirtóide.

O maior gênero da subtribo Myrtinae, com mais de 70 espécies, distribui-se do México ao norte da Argentina, sendo o seu centro de diversidade o Brasil (Landrum \& Kawasaki 1997). Na Restinga da Marambaia ocorrem duas espécies.

7.1. Psidium cattleyanum Sabine, Trans. Hort. Soc. London 4: 215, tab. 2. 1821.

Tipo: não localizado.

Fig. 97-102

Arbusto a árvore de até 10 metros de altura; ramos jovens de coloração acastanhada, pubérulos a glabrescentes, ramos velhos de coloração acinzentada; 


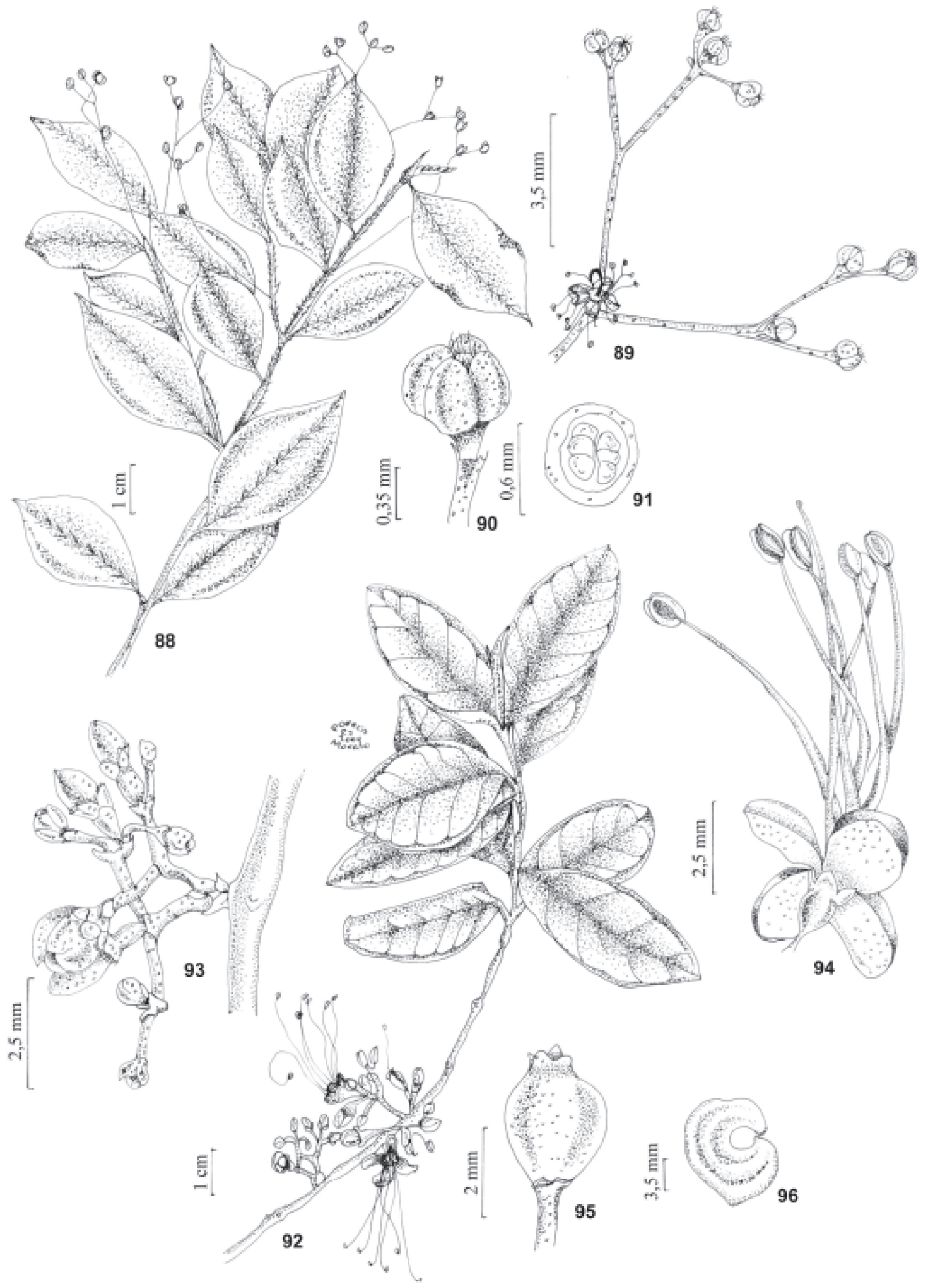

Figuras 88-91. Blepharocalyx salicifolius (Kunth) O. Berg: 88. Ramo. 89. Inflorescência em dicásio. 90. Botão floral. 91. Corte transversal do ovário (Souza 165). Figuras 92-96. Myrrhinium atropurpureum Schott var. atropurpureum: 92. Ramo. 93. Inflorescência em dicásio. 94. Flor (Souza 270). 95. Fruto. 96. Semente (Souza 238). 
tronco com casca externa laminada desfoliante em placas rígidas, deixando um aspecto liso e avermelhado. Folhas obovadas ou elíptico-obovadas, ápice obtusoacuminado ou obtuso, base cuneada ou decurrente, bordo revoluto, coriáceas, discolores; 55-135x 25-65 mm; nervura principal plana a sulcada na face adaxial e saliente na face abaxial; nervuras secundárias 8-10 pares, pouco visíveis na face adaxial, salientes e evidentes na face abaxial; nervura marginal 2-4 mm do bordo; nervura intramarginal quase inconspícua, muito próxima ao bordo; pecíolo 5-10 $\mathrm{mm}$ compr. Inflorescências em mônades axilares, em nós folhosos basais ou ramifloros; antopódio 7-15 mm compr.; profilos triangulares, 1,5-2 $\mathrm{mm}$ compr., pubescentes, decíduos antes da antese. Botões florais globosoobovados, 7-12×5-10 mm; botão floral com cálice parcialmente fechado e uma pequena abertura apical, lobos caliciniais indistintos, abrindo-se em 4-5 lobos irregulares. Fruto globoso ou obovado, até $25 \mathrm{~mm}$ diâm., vermelho quando maduro.

Distribuição geográfica: distribui-se em toda a parte oriental do Brasil, chegando até o nordeste do Uruguai; é muito abundante nas restingas (Legrand \& Klein 1977). Nas restingas do Rio de Janeiro ocorre nas seguintes áreas: Marambaia, Jacarepaguá e Maricá. $\mathrm{Na}$ Restinga da Marambaia foi encontrada na formação arbustiva fechada de cordão arenoso, floresta inundável e na floresta de cordão arenoso.

Floração: de novembro a dezembro. Frutificação: de novembro a junho.

Comentário: a espécie apresenta frutos comestíveis, muito apreciados, sendo comumente cultivada.

Nome comum: araçá, araçá-da-praia, araçávermelho.

Material examinado: BRASIL. Rio de Janeiro: Angra dos Reis, Ilha Grande, Trilha da Mãe d'Água, 9/XI/2000, fl., Pinheiro 601 (RB). Mangaratiba, Restinga da Marambaia, Praia da Armação, complexo florestal inundável, 3/VI/2000, fr., Menezes 669 (RBR); próximo à Lagoa Vermelha, 14/II/2004, fr., Souza 307 (RBR). Paraty, Praia Negra, 23/XI/1990, fl., Farney 2507 (RB). Rio de Janeiro, Restinga da Marambaia, floresta de duna, 9/VI/2001, vg., Souza 208 (RBR); Restinga da Tijuca, 21/III/1943, fr., Machado s.n. (RB).

7.2. Psidium guineense Sw., Prod.: 77. 1788.

Tipo: Insula principis Africes, in Domingo culta, Swartz s.n., s.d. (S).

Fig. 103-108
Arbusto de até 1,5 metros de altura; ramos novos, pecíolos, face abaxial das folhas, quando novas também a adaxial, inflorescências e flores com indumento castanho-avermelhado, viloso; tronco com casca externa laminada desfoliante em placas rígidas, deixando um aspecto liso e acastanhado. Folhas obovadas, elípticas ou oblongas, ápice arredondado, obtuso, agudo ou acuminado; base aguda a cuneada, coriáceas, discolores; 40-105×25-50 mm; nervura principal sulcada a plana na face adaxial e saliente na abaxial; nervuras secundárias 7-10 pares, visíveis na face adaxial, salientes na face abaxial; nervura marginal ausente; pecíolo 5-10 mm compr. Flores em dicásio trifloro ou mônades, axilares em nós folhosos basais; antopódio 5-15 mm compr.; profilos lanceolados ou lineares, 1-3 mm compr., decíduos. Botões florais constritos logo acima do ovário com forma de "8", globo estaminal mais largo que o ovário, $10-14 \times 5 \mathrm{~mm}$; cálice totalmente fechado, rompendo-se irregularmente em 4-5 lobos. Fruto globoso, até $20 \mathrm{~mm}$ diâm., amarelo quando maduro.

Distribuição geográfica: ocorre desde o México até a Argentina (Legrand \& Klein 1977), comumente encontrada em ambientes secos ou degradados. Nas restingas do Rio de Janeiro ocorre nas seguintes áreas: Marambaia, Maricá e Barra de São João. Na Restinga da Marambaia foi encontrada na floresta de cordão arenoso, nas áreas pertubadas.

Floração: de setembro a março. Frutificação: de setembro a março.

Comentário: apresenta grande variação morfológica e é facilmente confundida com Psidium guajava L., diferindo principalmente pelas folhas menores, nervuras secundárias em menor número e mais distanciadas entre si, além de apresentar a face abaxial das folhas vilosa. A espécie só foi encontrada na formação florestal de cordão arenoso, em trechos que sofreram pertubações ambientais, demonstrando ser uma espécie com características pioneiras ou ruderais.

Nome comum: araçá, araçá-azedo.

Material examinado: BRASIL. Rio de Janeiro: Mangaratiba, Restinga da Marambaia, Praia da Gaeta, 12/VI/2000, fr., Menezes 567 (RBR); próximo à Lagoa Vermelha, 12/VI/2000, fr., Menezes 573 (RBR); 12/VI/2000, fl., Menezes 587 (RBR).

\section{Agradecimentos}

À Dra. Graziela M. Barroso (in memoriam), pelos valiosos ensinamentos; ao Marcos Sobral e Carolyn Proença, pelas sugestões; ao Luis Fernando 


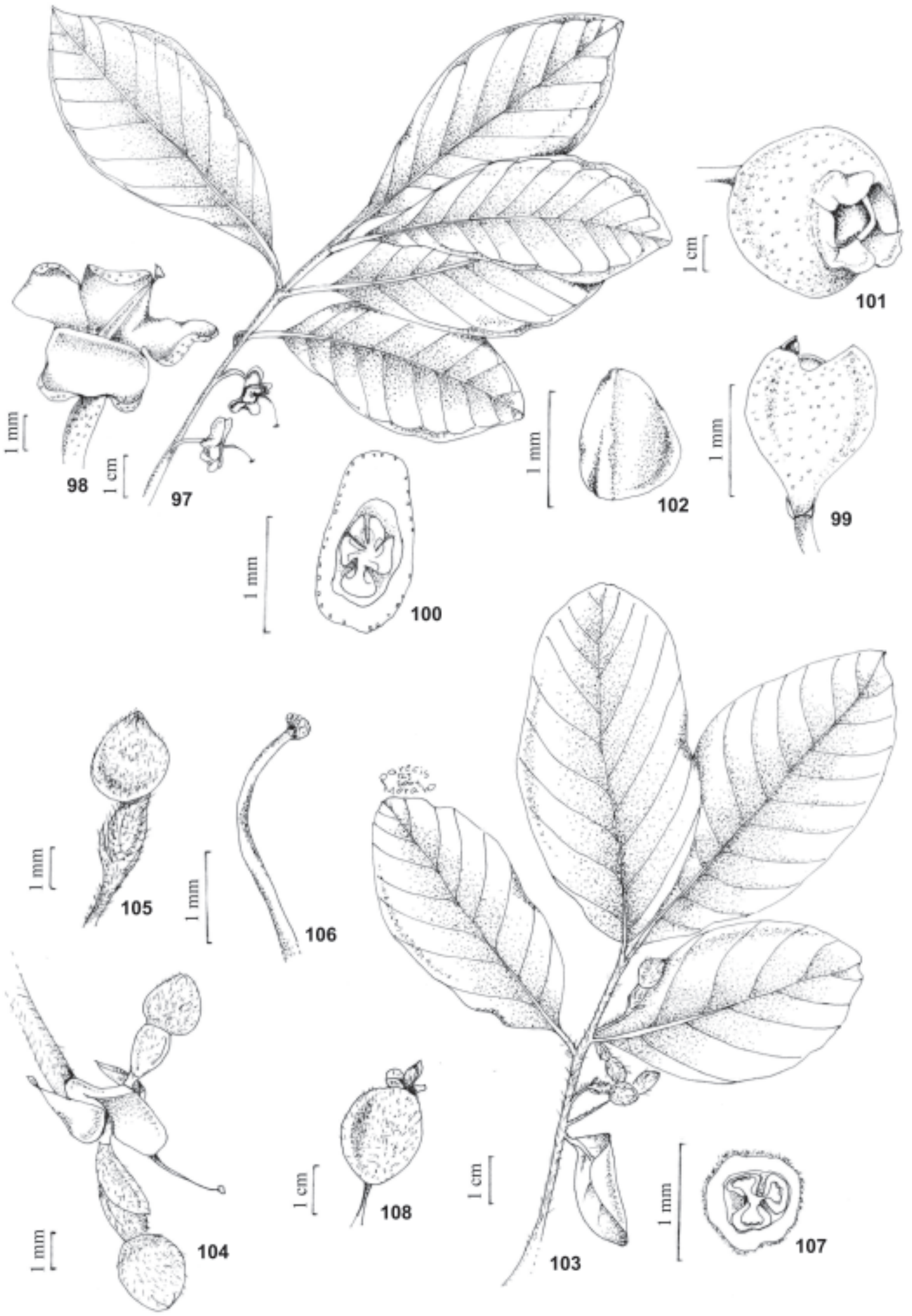

Figuras 97-102. Psidium cattleyanum Sabine: 97. Ramo. 98. Flor após antese (Pinheiro 601). 99. Botão floral. 100. Corte transversal do ovário (Farney 2507). 101. Fruto (Machado s.n). 102. Semente (Souza 307). Figuras 103-108. Psdium guineense Sw: 103. Ramo. 104. Inflorescência em dicásio. 105. Botão floral. 106. Estilete e estígma. 107. Corte transversal do ovário (Menezes 587). 108. Fruto (Menezes 573). 
T. Menezes, por toda contribuição no conhecimento da Marambaia; ao Campo de Provas da Marambaia (Exército) e Centro de Adestramento da Ilha da Marambaia (Marinha), por possibilitar o desenvolvimento deste estudo no local e pelo apoio fornecido; à FAPERJ, pela bolsa de Mestrado concedida ao primeiro autor; à Fundação O Boticário de Proteção à Natureza, pelo apoio fornecido ao Projeto Marambaia; à ilustradora Parecis Morato, pela dedicação.

\section{Referências bibliográficas}

Araujo, D.S.D. 2000. Análise florística e fitogeográfica das restingas do Estado do Rio de Janeiro. Tese de doutorado, UFRJ.

Barroso, G.M.; Peixoto, A.L.; Ichaso, C.L.F.; Costa, C.G.; Guimarães, E.F. \& Lima, H.C. 1984. Myrtaceae. In: Sistemática de Angiospermas do Brasil 2: 114-126. Viçosa, Ed. UFV.

Barroso, G.M. \& Peron, M. 1994. Myrtaceae. Pp. 261-296. In: M.P.M. de Lima \& R.R. Guedes-Bruni (orgs.). Reserva Ecológica de Macaé de Cima, Nova Friburgo, RJ: Aspectos Florísticos das Espécies Vasculares. Rio de Janeiro, Jardim Botânico do Rio de Janeiro.

Barroso, G.M. \& Marques, M.C.M. 1997. Myrtaceae. Pp. 314-382. In: M.C.M. Marques; A.S.F. Vaz \& R. Marquete (orgs.). Flórula da APA Cairuçu, Parati, RJ: espécies vasculares. Rio de Janeiro, Jardim Botânico do Rio de Janeiro.

Barroso, G.M.; Morim, M.P.; Peixoto, A.L. \& Ichaso, C.L.F. 1999. Frutos e Sementes: Morfologia aplicada à sistemática de dicotiledôneas. Viçosa, Ed. UFV.

Berg, O. 1855. Revisio Myrtacearum Americae. Linnaea 27: 1-128.

Berg, O. 1856a. Revisio Myrtacearum Americae. Linnaea 27: 129-384.

Berg, O. 1856b. Revisio Myrtacearum Americae. Linnaea 27: $385-512$.

Berg, O. 1857. Myrtaceae. In: C.P.F. Martius (ed.). Flora Brasiliensis 14: 1-468.

Berg, O. 1858. Myrtaceae. In: C.P.F. Martius (ed.). Flora Brasiliensis 14: 469-528.

Berg, O. 1859. Myrtaceae. In: C.P.F. Martius (ed.). Flora Brasiliensis 14: 529-656.

Briggs, B.G. \& Johnson, L.A.S. 1979. Evolution in the Myrtaceae - Evidence from inflorescence struture. Proceedings of the Linnean Society of New South Wales 102 : $157-256$.

Candolle, A.P. 1826. Dict. Classique d'hist. naturelle. v. 11. Paris.

Harrington, H.D. \& Durrel, L.W. 1957. How identify plants. Chicago, The Swallow Press.
Hickey, L.J. 1973. Classification of the architecture of Dicotyledonous leaves. American Journal of Botany 60: 17-33.

Holmgren, P.K.; Holmgren, N.H. \& Barnett, L. 1990. Index Herbariorum. 8. ed. New York, New York Botanical Garden.

Kiaerskou, H. 1893. Enumeratio Myrtacearum brasiliensium. In: E. Warming (ed.). Symbolarum ad Floram Brasiliae Centralis Cognoscendam 39: 1-200.

Landrum, L.R. \& Kawasaki, M.L. 1997. The genera of Myrtaceae in Brazil: an illustrated synoptic treatment and identification keys. Brittonia 49: 508-536.

Landrum, L.R 1986. Campomanesia, Pimenta, Blepharocalyx, Legrandia, Acca, Myrrhinium and Luma - Myrtaceae. Flora Neotropica monograph 45: 1-178.

Legrand, C.D. \& Klein, R.M. 1969. Mirtáceas: 2. Eugenia. In: R. Reitz (ed.). Flora Ilustrada Catarinense: 45-216.

Legrand, C.D. \& Klein, R.M. 1977. Mirtáceas: 8. Campomanesia, 9. Feijoa, 10. Britoa, 11. Myrrhinium, 12. Hexachlamys, 13. Siphoneugena, 14. Myrcianthes, 15. Neomitranthes, 16. Psidium. In: R. Reitz (ed.). Flora Ilustrada Catarinense: 570-730.

Marchiori, J.N.C. 1995. Elementos de dendrologia. Santa Maria, Ed. UFSM.

McVaugh, R. 1956. Nomenclatural notes on Myrtaceae and related families. Taxon 5: 133-147.

McVaugh, R. 1968. The genera of american Myrtaceae - an interim report. Taxon 17: 354-418.

McVaugh, R. 1969. The botany of the Guayana highland Part VIII - Myrtaceae. Memoirs of The New York Botanical Garden 18: 55-286.

Menezes, L.F.T. \& Araujo, D.S.D. 2005. Formações vegetais da Restinga da Marambaia. Pp. 67-120. In: L.F.T. Menezes; D.S.D. Araujo \& A.L. Peixoto (eds.). História Natural da Marambaia. Seropédica, Edur.

Ribeiro, J.E.L.S.; Hopkins, M.J.G.; Vicentini, A.; Sothers, C.A.; Costa, M.A.S.; Brito, J.M.; Souza, M.A.D.; Martins, L.H.P.; Lohmann, L.G.; Assunção, P.A.C.L.; Pereira, E.C.; Silva, C.F.; Mesquita, M.R. \& Procópi, L.C. 1999. Flora da Reserva Ducke: Guia de indentificação das plantas vasculares de uma floresta de terra-firme na Amazônia Central. Amazonas, INPA-DFID.

Sobral, M. 1987. La sinonimia de Eugenia punicifolia (Kunth) DC. (Myrtaceae). In: R. Spichiger (ed.). Notulae ad Floram paraquaiensem, 11-13. Candollea 42: 807-811.

Sobral, M. 1993. Sinopse de Myrciaria (Myrtaceae). Napaea 9: $13-41$.

Sobral, M. 2003. A família das Myrtaceae no Rio Grande do Sul. São Leopoldo, Editora Unisinos.

Souza, M.C.; Morim, M.P.; Conde, M.M.S. \& Menezes, L.F.T. 2007. Subtribo Myrciinae O. Berg na Restinga da Marambaia, Rio de Janeiro - Brasil. Acta Botanica Brasilica 21: 49-63.

Wilson, P.G.; O’Brien, M.M.; Gadek, P.A. \& Quinn, C.J. 2001. Myrtaceae revisited: a reassessmente of infrafamilial groups. American Journal of Botany 88: 2013-2025.

Versão eletrônica do artigo em www.scielo.br/abb e http://www.botanica.org.br/acta/ojs 